\title{
Emerging roles of pathogens in Alzheimer disease
}

\section{Judith Miklossy*}

Chronic spirochetal infection can cause slowly progressive dementia, cortical atrophy and amyloid deposition in the atrophic form of general paresis. There is a significant association between Alzheimer disease (AD) and various types of spirochete (including the periodontal pathogen Treponemas and Borrelia burgdorferi), and other pathogens such as Chlamydophyla pneumoniae and herpes simplex virus type-1 (HSV-1). Exposure of mammalian neuronal and glial cells and organotypic cultures to spirochetes reproduces the biological and pathological hallmarks of $A D$. Senile-plaque-like beta amyloid $(A \beta)$ deposits are also observed in mice following inhalation of $C$. pneumoniae in vivo, and $A \beta$ accumulation and phosphorylation of tau is induced in neurons by HSV-1 in vitro and in vivo. Specific bacterial ligands, and bacterial and viral DNA and RNA all increase the expression of proinflammatory molecules, which activates the innate and adaptive immune systems. Evasion of pathogens from destruction by the host immune reactions leads to persistent infection, chronic inflammation, neuronal destruction and $A \beta$ deposition. $A \beta$ has been shown to be a pore-forming antimicrobial peptide, indicating that $A \beta$ accumulation might be a response to infection. Global attention and action is needed to support this emerging field of research because dementia might be prevented by combined antibiotic, antiviral and anti-inflammatory therapy.

Alzheimer disease (AD) is characterised by a slowly progressive decline of memory and cognition. Alzheimer described the characteristic cortical senile plaques and neurofibrillary tangles in the brain of a 51-year-old woman with presenile dementia (Refs 1, 2). Because the presenile form, with onset before the age of 65 , is identical to the most common form of senile dementia, today, the term AD is used for the designation of both presenile and senile cases (Refs 3, 4).

Senile plaques were first described by Blocq and Marinesco (Ref. 5). Redlich (Ref. 6) first observed senile plaques in the brains of two patients with senile dementia. Recently, particularly from the use of the Gallyas silver technique (Ref. 7), neuropil threads or curly fibres were recognised as further characteristic

International Alzheimer Research Centre, Prevention Alzheimer Foundation, Martigny-Combe, Switzerland

*Corresponding author: Judith Miklossy, 1921 Martigny-Croix CP 16, 1921, Switzerland. E-mail: judithmiklossy@bluewin.ch 
lesions of AD. Granulovacuolar degeneration is another typical alteration of neurons (Ref. 8). Other important features include neuronal and synaptic loss (Ref. 9), Hirano bodies, reactive astrocytosis and microgliosis.

$\mathrm{AD}$ is a form of amyloidosis. The amyloid substance aggregated in the brain is a small, $\sim 4 \mathrm{kDa}$ amyloid beta peptide $(\mathrm{A} \beta)$. It is released by $\beta$ - and $\gamma$-secretase cleavage from a larger $120 \mathrm{kDa}$ transmembrane amyloid precursor protein (APP) (Refs 10, 11) and was purified and partially sequenced by Glenner and Wong (Ref. 12). APP exhibits features of a glycosylated cell-surface receptor and was shown to be a proteoglycan core protein (Ref. 13). APP is phylogenetically highly conserved and constitutively expressed by various cells other than neurons, including immune cells (Ref. 14). Human platelets, peripheral lymphocytes and leukocytes produce the major isoforms of APP, and after activation, they secrete amyloidogenic $\mathrm{A} \beta$ (Refs 15, 16, 17, 18).

$\mathrm{A} \beta_{1-42}$ has a higher ability to aggregate than the shorter $A \beta_{1-40}$ (Refs 19, 20). $A \beta$ exists in soluble nontoxic monomers, strongly toxic soluble oligomers and in the form of less toxic insoluble fibrils. The soluble oligomers of $\mathrm{A} \beta_{1-42}$ are the most toxic (Refs 21, 22, 23, 24, 25 , 26). They form annular or pore-like structures that are indistinguishable from a class of pore-forming bacterial toxins (Refs 24, 25 , 27), which cause rapid calcium influx through the targeted cell membranes (Refs 28, $29,30)$. Recent in vitro and in vivo studies showed that $A \beta$ is an antimicrobial peptide (AMP) that targets bacterial membranes (Ref. 31). AMPs have proinflammatory activities and have a role in innate immune responses (Ref. 31).

Neurofibrillary tangles and neuropil threads contain paired helical filaments (PHFs) (Refs 32, 33). The major component of PHFs is the microtubule-associated protein tau, which is in a pathological hyperphosphorylated state that abolishes microtubule assembly (Refs 34, 35). Sequestration of peptidyl-prolyl cis/trans isomerase NIMA interacting 1 (PIN1) is one theory that explains the formation of these pathological fibrillar lesions (Ref. 36).

Various hypotheses have been proposed to explain the pathogenesis of AD (Refs 37, 38, 39, 40, 41, 42, 43). A significant proportion of earlyonset $\mathrm{AD}$ is inherited as an autosomal dominant trait (Ref. 44). Missense mutations of the APP gene located on chromosome 21 (Refs 45, 46) are responsible for $5 \%$ of all early-onset familial AD cases (Ref. 44). Presenilin-1 (PS1) gene mutations are most frequent in early-onset familial AD (Refs 37, 47). More than 80 different PS1 missense mutations or amino acid deletions have been identified (Refs 37, 47, 48, 49, 50). Presenilin-2 (PS2) mutations are responsible for another subset of early-onset familial AD (Refs 47, 51). As originally shown by Hardy (Ref. 39), mutations in these pathogenic genes alter the processing of APP and result in an increase in amyloidogenic $A \beta_{1-42}$ and $A \beta_{1-43}$ (Refs 50, 52, 53, 54, 55, 56, 57, 58, 59). The epsilon 4 allele of apolipoprotein E (APOE $\varepsilon 4)$ is an important risk factor for late-onset $A D$, which also correlates with increased $A \beta$ burden (Ref. 60). Finally, there is an association between $\mathrm{AD}$ and polymorphisms of various other genes, which include a growing number of genes, implicated in immune defence mechanisms (Refs 61, 62).

The relation between the two major biological markers of $\mathrm{AD}, \mathrm{A} \beta$ (Refs 38, 41) and hyperphosphorylated tau (Refs 34, 35), is not clear. Soluble $A \beta$ and tau strongly interact (Ref. 63), and APP is expressed in neurofibrillary tangles (Ref. 64), suggesting that these apparently different pathologies are linked.

Alterations of various neurotransmitters, neuropeptides and hormones are reported to occur in AD (Refs 65, 66, 67, 68). The cholinergic hypothesis is based on the alteration of acetylcholine synthesis, transport and release (Refs 69, 70). Oxidative damage to proteins, lipids and nucleic acids (Refs 71, 72, 73, 74) and mitochondrial dysfunction (Ref. 75) are also significant contributors to the pathogenesis of $\mathrm{AD}$. The role of various metals, including aluminium (Refs 76, 77) and iron (Ref. 78) was proposed several decades ago. Direct modulation of APP processing by metal ions, including $\mathrm{Ca}^{2+}$, $\mathrm{Zn}^{2+}, \mathrm{Fe}^{2+} / \mathrm{Fe}^{3+}$ and $\mathrm{Al}^{3+}$, suggests that disrupted metal homeostasis also leads to increased APP levels (Ref. 79). The calcium homeostasis hypothesis indicates that sustained deregulation of cytosolic calcium represents the common final pathway for neuronal death in AD (Ref. 80). Dysregulation of ubiquitylation or glycosylation processes (Refs 81, 82) has been shown in AD. Vascular lesions, including cerebral hypoperfusion and disturbed brain 
microcirculation, are also important factors (Refs 83, 84, 85, 86, 87, 88, 89, 90, 91). Factors representing a risk for atherosclerosis (Refs 92, 93), are also risk factors for AD. Early involvement of the olfactory system in $\mathrm{AD}$ (Ref. 94) led to the 'olfactory hypothesis', which suggests that putative pathogenic agents might access the brain by the olfactory pathways (Refs 95, 96, 97). Deregulation of various signalling pathways, apoptosis, craniocerebral trauma, exercise, environmental and nutritional factors, among others, are also implicated in the pathogenesis of $\mathrm{AD}$.

The critical role of chronic inflammation and the importance of interleukin (IL)-1 signalling in $\mathrm{AD}$ is now widely recognised (Refs 98, 99, 100). A series of inflammatory mediators, including cytokines, chemokines, proteases, adhesion molecules, free radicals, pentraxins, prostaglandins, anaphylatoxins and activated complement proteins, is present at the site of cortical lesions in AD (Refs 101, 102, 103). The membrane attack complex (MAC, C5b-9) is also associated with plaques, tangles and neuropil threads (Refs 100, 104). Use of nonsteroidal antiinflammatory drugs reduces the risk of $\mathrm{AD}$ (Refs 105, 106, 107, 108).

Nearly a century ago, Fischer, Alzheimer and their colleagues (Refs 2, 109) discussed the possibility that microorganisms could have a role in the formation of senile plaques. That a slow-acting unconventional infectious agent, acquired at an early age and requiring decades to become active, might be involved in $\mathrm{AD}$ was considered by several authors (Refs 110, 111). A growing number of recent observations indicate that infectious agents are involved in the pathogenesis of AD. Here, I review historical and recent observations on infectious agents related to $\mathrm{AD}$ and analyse the significance of the association and causal relationship.

\section{Analogies between $A D$ and the atrophic form of general paresis}

Historical observations show that the clinical and pathological hallmarks defining $\mathrm{AD}$ are similar to those occurring in the atrophic form of general paresis, a chronic bacterial infection (Refs 112, 113, 114, 115, 116, 117, 118). In 1913, Noguchi and Moore (Ref. 119) provided conclusive evidence that spirochetes are responsible for slowly progressive dementia, cortical atrophy and local amyloidosis.
General paresis of the insane, paretic dementia or dementia paralytica is a chronic meningoencephalitis caused by the direct invasion of brain parenchyma by Treponema pallidum. Two forms are distinguished: the infiltrative and the atrophic form (Refs 114, 117). In the infiltrative form, mood disorders and psychosis predominate, and lymphoplasmocytic meningoencephalitis is the characteristic pathology (Refs 117, 118). The atrophic form is characterised by slowly progressive dementia and cortical atrophy, which is accentuated in the frontotemporal regions (Refs 114, 115). Spirochetes form masses, plaques or colonies (Fig. 1) and disseminate as individual filaments, which are restricted to the cerebral cortex (Fig. 1) (Refs 114, 115). These spirochetal masses and individual spirochetes are morphologically identical to senile plaques (Fig. 1) and neuropil threads (Fig. 1). Pacheco e Silva (Refs 114, 115), reported that the number of spirochetes and spirochetal 'plaques', which are numerous in the hippocampus and frontal cortex, increases in parallel with the severity of cortical atrophy (Refs 114, 115). Lymphoplasmocytic infiltrates are absent. Severe neuron loss is accompanied by reactive microgliosis and astrocytosis and by accumulation of 'paralytic iron' (Ref. 120). The occurrence of neurofibrillary tangles is also documented in general paresis (Refs 113, 118, $121,122)$, and the local amyloid (Ref. 123), as in $\mathrm{AD}$, consists of $\mathrm{A} \beta$ (Ref. 124).

\section{Analogies between AD and other age- related chronic inflammatory disorders}

Pathogens can produce slowly progressive chronic diseases. Following the pioneering work of Warren and Marshall (Ref. 125), it is today established that Helicobacter pylori causes stomach ulcers. Infectious agents are also linked to atherosclerosis, cardio- and cerebrovascular disorders (Refs 126, 127, 128, 129, 130, 131, 132, 133, 134), chronic lung diseases (Refs 135, 136, 137), inflammatory bowel diseases and neuropsychiatric disorders (Refs 138, 139, 140, 141, 142, 143).

Chlamydophila (Chlamydia) pneumoniae (Refs 126, 127), H. pylori (Refs 128, 129) and several periodontal pathogens, including invasive oral spirochetes (Refs 130, 131) and herpes viruses, have been found in human atherosclerotic lesions. Some of them also enhanced atherosclerosis in experimental animals 
(Refs 131, 132). These pathogens were also reported to be associated with AD (Refs 144, 145, 146, 147, 148, 149, 150, 151).

Epidemiological studies have confirmed that several of these chronic inflammatory disorders are associated with AD (Refs 152, 153, 154, 155). In addition, they are all linked to periodontal polybacterial disorders, which are primarily caused by Gram-negative bacteria (Refs 156, 157, 158, 159). Spirochetes and herpes viruses are predominant periodontal pathogens (Refs 160, 161, 162, 163), and C. pneumoniae is a major upper respiratory tract pathogen. An infectious origin might give a comprehensive explanation of the common cellular and molecular mechanisms, inflammatory processes and common inflammatory gene polymorphisms involved in these chronic inflammatory disorders and $\mathrm{AD}$ (Refs 61, 164, 165).

Evidence for the association of pathogens with AD

\section{Spirochetes}

Spirochetes are Gram-negative, helical bacteria, which possess endoflagella, taxonomically distinguishing them from other bacteria. There are over 200 different spirochetal species or phylotypes (Ref. 166). Spirochetes are causative agents of important human diseases such as syphilis, pinta, yaws, bejel, Lyme disease, Vincent angina, relapsing fever, leptospirosis, ulcerative gingivitis and various periodontal disorders (Ref. 167). The major Borrelia species causing Lyme disease are $B$. burgdorferi

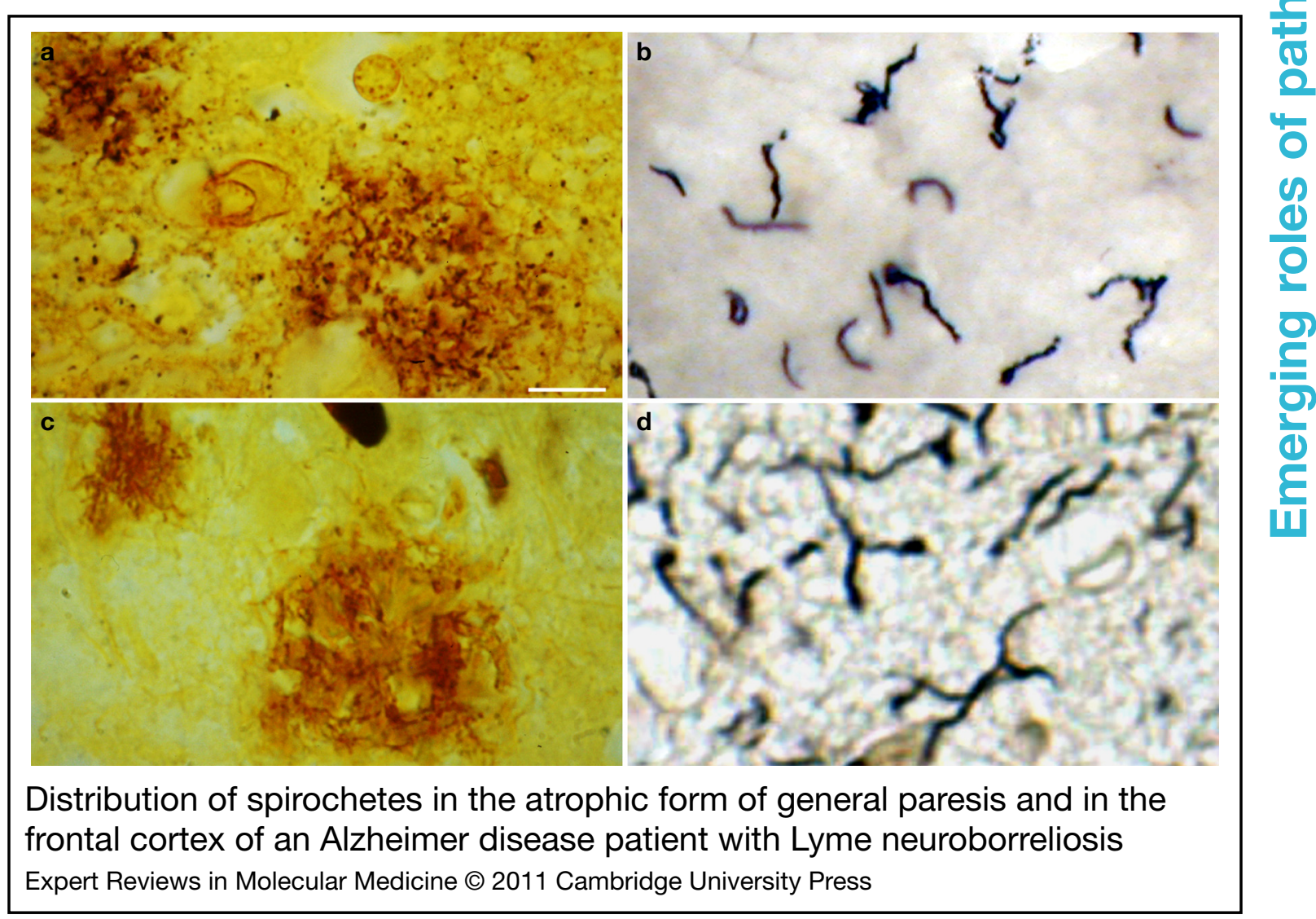

Figure 1. Distribution of spirochetes in the atrophic form of general paresis and in the frontal cortex of an Alzheimer disease (AD) patient with Lyme neuroborreliosis. Spirochetes form plaque-like masses (a,c) and disseminate as individual filaments $(b, d)$ in general paresis $(a, b)$ and $A D(c, d)$, which are identical to senile plaques and curly fibres. (a,c) Bosma Steiner silver technique for the visualisation of spirochetes. (b) T. pallidum-specific polyclonal antibody. (d) Gallyas silver technique. Scale bars: $50 \mu \mathrm{m}$ (a), $40 \mu \mathrm{m}$ (c), $10 \mu \mathrm{m}(\mathrm{b}, \mathrm{d})$. All images were obtained from previously published studies: a (Ref. 124); b (Ref. 175); c, d (Ref. 149). 
(Ref. 170), B. afzelii, B. garinii and B. valaisiana. Relapsing fever is caused by B. recurrentis. Oral spirochetes are predominant periodontal pathogens that are highly prevalent in the population and comprise diverse Treponema species (Refs 166, 171). Several are invasive (Refs 172, 173): they include $T$. denticola, $T$. socranskii, T. pectinovorum, T. amylovorum, T. lecithinolyticum, T. maltophilum, T. medium and T. putidum (Refs 166, 171, 174). T. vincentii causes Vincent angina, a necrotising fusospirochetal disease (Ref. 167).

Because spirochetes are strongly neurotropic (Ref. 167), it was expected that several types of spirochetes, in an analogous way to T. pallidum, might cause dementia, plaque- and tangle-like lesions, $\mathrm{A} \beta$ deposition and consequently might be involved in the pathogenesis of AD. To detect all types of spirochete, neutral techniques need to be used (Ref. 146). Using dark-field microscopy, spirochetes were detected in the cerebrospinal fluid (CSF), in the blood and in the brain in 14 definite $\mathrm{AD}$ cases tested (Table 1). Spirochetes were not found in 13 agematched controls without any AD-type cortical changes (Ref. 146). Silver-stained helically shaped spirochetes were also detected by electron microscopy. Spirochetes were isolated from the cerebral cortex in these $14 \mathrm{AD}$ cases (Table 1), and in three of them, they were cultivated from the brain in a selective medium for B. burgdorferi (Ref. 146). Spirochetes were detected and isolated from the brains of eight additional $\mathrm{AD}$ cases derived from another laboratory and in the blood of five living patients with clinically diagnosed AD-type dementia (Ref. 186; Table 1). Four healthy controls did not show spirochetes. Taxonomical analyses showed that the helically shaped microorganisms belong to the order Spirochaetales (Ref. 187). To ensure the consistency of these results, the detection of spirochetes was also performed using various other techniques, including histochemistry, darkfield microscopy, atomic force microscopy, electron microscopy and immunoelectron microscopy, immunohistochemistry using spirochete and bacterial peptidoglycan (PGN)specific antibodies (Refs 146, 147, 149, 186, 187, $176,175,188,189)$, and detection of specific and nonspecific bacterial DNA (Refs 149, 176). PGN is the building block of the cell wall of Gramnegative and Gram-positive bacteria; however, mycoplasma and chlamydiae lack detectable PGN (Refs 190, 191). The morphology of spirochetes detected by spirochete- or PGNspecific antibodies is identical (Fig. 2; compare also Fig. $7 \mathrm{G}$ and $\mathrm{H}$ of Ref. 175). PGNimmunoreactive spirochetes were detected in 32 definite $\mathrm{AD}$ cases and in 12 cases with mild or moderate AD-type cortical changes.

Other authors found no evidence of spirochetes in the brains of seven AD cases by dark-field or electron microscopy (Ref. 192). However, spirochetes were observed in the blood of one of 22 living patients with AD-type dementia (Table 1). The spirochete observed by these authors corresponded to the vegetative, regularly spiral form. They suggested that it could correspond to an oral spirochete. Whether the atypical, pleomorphic spirochetal forms, which commonly occur in infected tissues, blood and CSF (Refs 167, 175, 177, 193), were considered by the authors is not clear.

\section{Periodontal pathogen Treponemas}

Using molecular and immunological techniques, six of seven periodontal Treponema species, namely T. socranskii, T. pectinovorum, T. denticola, T. medium, T. amylovorum and T. maltophilum, were identified in the brains of $\mathrm{AD}$ patients using species-specific polymerase chain reaction (PCR; Table 1). At least one oral Treponema species was present in 14 of 16 AD brains, compared with 4 out of 18 controls (Ref. 147). T. pectinovorum and $T$. socranskii antigens were observed in 15 of $16 \mathrm{AD}$ brains and in 7 of 18 controls. In the hippocampus and in the frontal cortex. Six different Treponema species were detected in one $\mathrm{AD}$ patient, five species in four, four or three species each in one AD case, and one species in seven AD brains. Two Treponema species were observed in one control and one species in the other three positive controls. These results reinforce previous observations (Ref. 146) and indicate that these periodontal pathogen spirochetes, in an identical way to $T$. pallidum and B. burgdorferi, have the ability to invade the brain, persist in the brain, and cause dementia, cortical atrophy and amyloid deposition.

\section{Borrelia burgdorferi}

The causative agent of Lyme disease is transmitted by the bite of infected ticks (Ref. 170). Neurological complications occur in about $15 \%$ of affected 


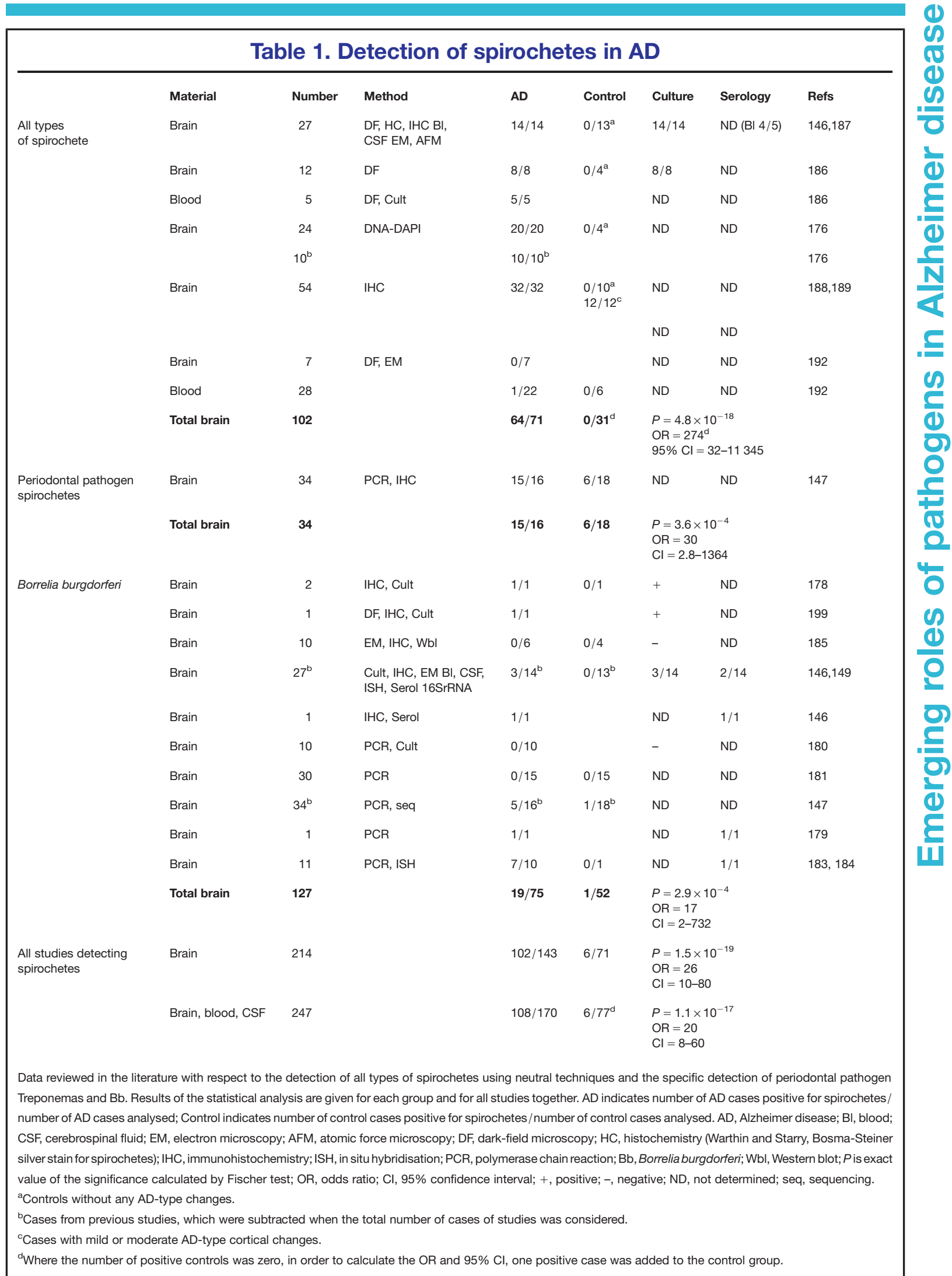




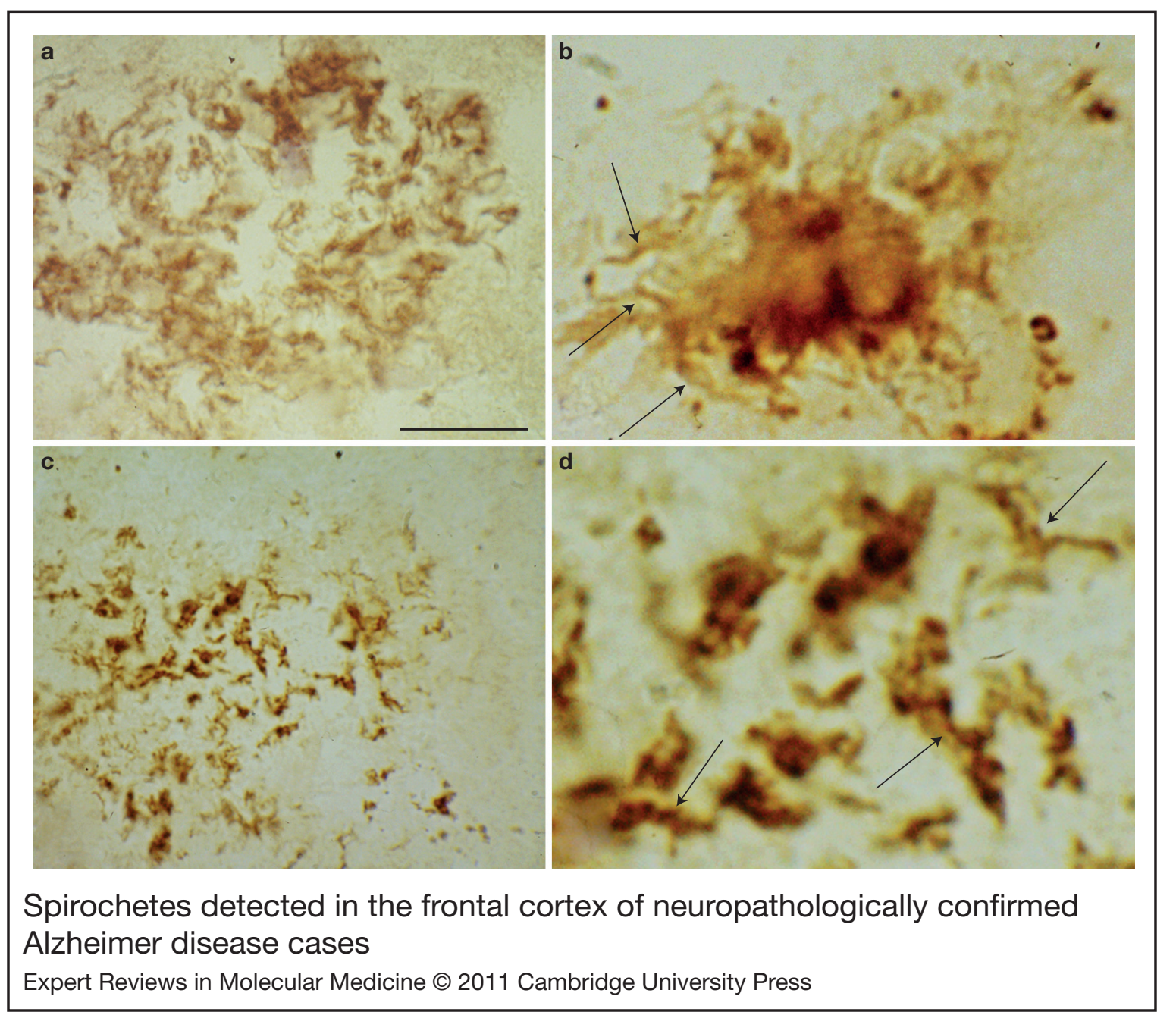

Figure 2. Spirochetes detected in the frontal cortex of neuropathologically confirmed Alzheimer disease cases. Spirochetes in an immature senile plaque detected by a cocktail of antibodies against Borrelia burgdorferi (a), in a mature plaque detected by in situ hybridisation (b, arrows) using Borrelia-specific probes, and in an amorphous plaque detected by antibacterial peptidoglycan antibody (c). (d) The central part of panel $\mathrm{c}$ at higher magnification. Arrows indicate helical spirochetes with the same morphology as observed in b. Scale bars: $80 \mu \mathrm{m}$ (a), $30 \mu \mathrm{m}$ (b), $80 \mu \mathrm{m}$ (c), $20 \mu \mathrm{m}$ (d). Images are from previously published studies: a,b (Ref. 149); c,d (Ref. 188).

individuals. Dementia and subacute presenile dementia both occur in Lyme disease (Refs 146, $149,194,195,196,197,198)$. B. burgdorferi was first detected in the brains of two AD patients (Table 1) by MacDonald and Miranda (Ref. 178) and MacDonald (Ref. 199). This spirochete was detected in the cerebral cortex by dark-field microscopy and with a specific antibody against B. burgdorferi. This species was also detected and cultivated from the brains of three definite $A D$ cases in an initial series of $14 \mathrm{AD}$ cases (Ref. 146). Molecular characterisation, using 16S
rRNA gene sequence analysis, identified these spirochetes as B. burgdorferi sensu stricto (s.s.) (Ref. 149). Electron microscopy analysis confirmed that these spirochetes possess 10-15 endoflagella typical of Borrelia species. Two of the three $\mathrm{AD}$ patients had a positive CSF serology for B. burgdorferi, and the $31 \mathrm{kDa}$ outer surface protein A (OspA) band, which is highly specific for $B$. burgdorferi, was detected by western blot in these three AD cases (Ref. 149). The pathological changes found in the brain were identical to those occurring in the atrophic 
form of general paresis (Ref. 149). The cortical distribution of spirochetes in masses or colonies was identical to those of senile plaques, and the morphology of individual spirochetes was identical to those of curly fibres (Ref. 149). B. burgdorferi antigens colocalised with $A \beta$ in cortical plaques and in leptomeningeal and cortical arteries containing amyloid deposits. Neurofibrillary tangles were also immunoreactive for B. burgdorferi. OspA and flagellin genes were detected in AD-type lesions using in situ hybridisation (ISH) (Fig. 2b). In additional AD patients with concurrent Lyme neuroborreliosis, B. burgdorferi-specific antigens (Ref. 146) and DNA (Ref. 179) were observed. Using species-specific PCR, B. burgdorferi DNA was detected in 5 of $16 \mathrm{AD}$ patients tested and in 1 of 18 controls, all of which also had oral Treponema spirochetes (Ref. 147). Finally, B. burgdorferi-specific DNA was detected by both ISH and PCR in the hippocampus in 7 of 10 pathologically confirmed AD cases (Refs 183, 184) (Table 1).

Pappolla and colleagues (Ref. 185) failed to detect B. burgdorferi in six AD patients. They stated that they could not exclude other spirochetes not detected by their methods. In all other studies where B. burgdorferi was not detected, evidence is lacking on whether the analysed AD patients had Lyme neuroborreliosis or not (Refs 180, 181) (Table 1). Similarly, the analysis of the serology of B. burgdorferi alone, as a result of the low incidence of Lyme dementia compared with $\mathrm{AD}$, might give false-negative results (Refs 180, 182). To demonstrate the role of B. burgdorferi, AD patients with Lyme neuroborreliosis should be analysed.

Taken together, these observations show that various authors detected and cultivated various types of spirochetes from the brains of $\mathrm{AD}$ patients. Coinfection with several types of spirochetes occurs.

\section{Chlamydophyla pneumoniae}

Several authors reported the existence of an association between C. pneumoniae, an obligate intracellular respiratory pathogen, and AD (Refs 144，200，201，202, 203) (Table 2). C. pneumoniae-specific DNA was detected in the brains in $90 \%$ of sporadic AD patients and in 5\% of controls (Ref. 144) (Table 2). Two mRNAs, encoding KDO transferase and a $376 \mathrm{kDa}$ protein, specific to $C$. pneumoniae, were also identified in frozen $\mathrm{AD}$ brain tissue by reverse transcriptase-PCR (RT-PCR).

Immunohistochemical analyses of $\mathrm{AD}$ brains showed C. pneumoniae in microglia, perivascular macrophages and astrocytes, and in about 20\% of neurons (Refs 144, 200, 201, 203, 207, 211). They were commonly found in brain regions showing the characteristic neuropathology of AD (Refs 144, 200, 201). The presence of C. pneumoniae in the brains of $\mathrm{AD}$ patients was also confirmed by immunoelectron microscopy using specific monoclonal antibody against the outer membrane protein of C. pneumoniae. Electron and immunoelectron microscopy identified both chlamydial elementary bodies and reticulate bodies (RBs) (Refs 212, 144). That the replicative $\mathrm{RB}$ form was also detected in glial cells, neurons and pericytes indicates that a viable and transcriptionally active form of the microorganism is present in these cells (Refs 201, 213, 214, 215). Pleomorphic forms of C. pneumoniae were also observed (Ref. 213). C. pneumoniae-specific DNA was detected in the CSF in a significantly higher number of cases in $\mathrm{AD}$ patients $(43.9 \%)$ than in controls $(10.6 \%)$ (Ref. 202). C. pneumoniae was cultured from various brain samples of $\mathrm{AD}$ patients originating from different geographic regions of North America (Refs 144, 201, 215) and was also isolated from the CSF (Ref. 202). Tor-1 and Phi-1 isolates were characterised by PCR assays targeting C. pneumoniae-specific genes Cpn0695, Cpn1046 and tyrP. Two groups, using paraffinembedded brain samples, failed to detect C. pneumoniae in $\mathrm{AD}$ or in controls by PCR (Refs 216, 217). In another study, C. pneumoniae was detected in 2 of $15 \mathrm{AD}$ cases and in 1 of 5 controls (Ref. 204).

\section{Other bacteria}

Propionibacterium acnes, an atypical anaerobic bacterium, was identified in biopsy specimens of the frontal cortex in three of four AD patients and in one of five controls with cerebral tumour. The $P$. acnes positive control was an elderly patient with cardiovascular risk factors and glioblastoma (Ref. 205). P. acnes was identified by microbiological methods and by gas chromatography. The bacterium was cultivated from frontal cortical biopsy specimens in Schaedler blood agar, at $35^{\circ} \mathrm{C}$, under anaerobic conditions (Refs 205, 206). P. acnes has long been considered to be a commensal bacillus of the 
Table 2. Detection of Chlamydophyla pneumoniae and other bacteria in AD

\begin{tabular}{|c|c|c|c|c|c|c|}
\hline & Material & Number & Method & $A D$ & Control & Refs \\
\hline \multirow[t]{9}{*}{ C. pneumoniae } & Brain & 38 & $\begin{array}{l}\text { PCR, EM, IHC, } \\
\text { RT-PCR, Cult }\end{array}$ & $17 / 19$ & $1 / 19$ & 144 \\
\hline & Brain & 25 & PCR, IHC & $0 / 25$ & & 216 \\
\hline & Brain & 20 & PCR, IHC & $0 / 20$ & & 217 \\
\hline & Brain & 20 & PCR, Cult & $2 / 15^{\mathrm{a}}$ & $1 / 5^{a}$ & 204 \\
\hline & Brain & 21 & PCR, ISH & $21 / 21$ & $0 / 1$ & 200 \\
\hline & Brain & 52 & $\begin{array}{l}\text { PCR, Cult, } \\
\text { RT-PCR }\end{array}$ & $20 / 25$ & $3 / 27$ & 201 \\
\hline & CSF & 104 & PCR, Cult & $25 / 57$ & $5 / 47$ & 202 \\
\hline & $\begin{array}{l}\text { Total } \\
\text { brain }\end{array}$ & 177 & $\begin{array}{l}P=4.5 \times 10^{-7} \\
\mathrm{OR}=8.7 \\
\mathrm{Cl}=3.1-29.5\end{array}$ & $60 / 125$ & $5 / 52$ & \\
\hline & $\begin{array}{l}\text { Brain and } \\
\text { CSF }\end{array}$ & 281 & $\begin{array}{l}P=9.8 \times 10^{-11} \\
\mathrm{OR}=7.8 \\
\mathrm{Cl}=3.7-17.8\end{array}$ & $85 / 182$ & $10 / 99$ & \\
\hline $\begin{array}{l}\text { Propionibacterium } \\
\text { acnes }\end{array}$ & Brain & 3 & Cult & $3 / 4$ & $1 / 5$ & $219,22 C$ \\
\hline H. pylori & Stomach & 80 & $\mathrm{HC}$ & $44 / 50$ & $14 / 30$ & 225 \\
\hline
\end{tabular}

skin. Recent observations showed that P. acnes, the causative agent of acne vulgaris, is implicated in various infections, including brain abscesses, endocarditis, endophthalmitis and osteomyelitis (Refs 208, 209). P. acnes was also shown to be a predominant periodontal pathogen (Ref. 218). By haematogenous dissemination, it can reach and infect various organs, including the brain. Stabilisation of the clinical symptoms and memory improvement were observed in two AD cases treated with $P$. acnes-sensitive cephalosporine combined with enalapril and oestrogen (Ref. 206). The author pointed to microangiopathy as the underlying pathology (Refs 219, 220). Because the number of AD cases analysed is low, further studies should be encouraged to determine any association of $P$. acnes with $\mathrm{AD}$.

Actinomycetes have also been suggested to be involved in $\mathrm{AD}$, with an incidence four times higher than in other pathological conditions (Ref. 221). Ultrastructural analysis revealed that the fibronectin-immunopositive fibrillary lesions in senile plaques, which were negative for neuronal, glial and macrophage markers, are compatible with filamentous microorganisms and might correspond to Actinomycetes (Ref. 221). It is noteworthy that Actinobacillus actinomycetemcomitans is a frequent periodontal pathogen (Ref. 222) and that Nocardia asteroides was reported to cause Parkinson-like symptoms in experimental animals (Ref. 223).

Finally, the causative agent of stomach ulcers, H. pylori (Ref. 125), has also been suggested to be associated with AD (Refs 224, 225, 226). Serum IgG and IgA antibodies against H. pylori occurred in a higher percentage in the group of 30 AD patients compared with 30 controls (Ref. 224). The difference is statistically significant as determined by post-hoc 
comparison (Ref. 210). An almost twofold higher prevalence of gastric $H$. pylori infection was observed in clinically diagnosed AD patients and in patients with mild cognitive decline (Refs 225, 227) than in controls. H. pylori-specific IgG antibody levels were also significantly higher in the blood and CSF of AD patients than in controls (Ref. 226). Additional studies would be of interest in detecting whether $H$. pylori is present in the brain and to analyse the possibility of a causal relationship between $H$. pylori and AD.

\section{Herpes simplex virus type-1 (HSV-1) and other viruses}

HSV-1 is a common neurotropic virus that infects around $70 \%$ of the population after the age of 50 (Refs 150, 228, 229, 230). HSV-1 DNA was detected (Table 2) in brain samples using ISH in some elderly patients with dementia (Ref. 231). Three other studies failed to detect HSV-1 by ISH in AD or in control brains (Refs 232, 233, $234,235)$. Increasing numbers of recent observations have detected HSV-1 DNA in the brain in AD (Refs 150, 151, 228, 229, 236, 237, 238). Using PCR, Jamieson et al. (Ref. 150) observed HSV-1 DNA in the brains of a high proportion of elderly subjects, with or without $\mathrm{AD}$, which was absent or less frequent in young controls (Ref. 228). Several authors showed that HSV-1 is a significant risk factor (Table 3) when present in $\mathrm{AD}$ patients who are carriers of APOE \&4 (Refs 236, 237, 238), but this is not supported by Beffert et al. (Refs 239, 240). In situ PCR showed that HSV-1 DNA is localised to senile plaques (Ref. 243). Ninety per cent of senile plaques in $\mathrm{AD}$ and $80 \%$ in normal ageing subjects contained viral DNA (Ref. 241).

\begin{tabular}{|c|c|c|c|c|c|c|}
\hline \multicolumn{7}{|c|}{ Table 3. Detection of HSV-1 in AD } \\
\hline Material & Number & Method & $A D$ & Control & $P$ value & Refs \\
\hline Brain & 6 & $\mathrm{ISH}$ & $2 / 3$ & $1 / 3$ & 0.423 & 231 \\
\hline Brain & 5 & $\mathrm{ISH}$ & $0 / 3$ & $0 / 2$ & & 232 \\
\hline Brain & 23 & $\mathrm{ISH}$ & $0 / 18$ & $0 / 5$ & & 233 \\
\hline Brain & 13 & $\mathrm{ISH}$ & $0 / 8$ & $0 / 5$ & & 234 \\
\hline Brain & 6 & $\mathrm{ISH}$ & $0 / 4$ & $0 / 2$ & & 235 \\
\hline Brain & 14 & PCR & $8 / 8$ & $6 / 6$ & & 150 \\
\hline Brain & $36+10$ & PCR & $14 / 21$ & $\begin{array}{l}9 / 15(0 / 5 \\
\text { middle aged; } \\
0 / 5 \text { young })\end{array}$ & & 228 \\
\hline Brain & 155 & PCR & $73 / 98$ & $41 / 57$ & 0.485 & 229 \\
\hline Brain & 90 & PCR & $36 / 46$ & $28 / 44$ & $\begin{array}{l}0.295(P<0.0001 \\
A P O E \varepsilon 4)\end{array}$ & 236 \\
\hline Brain & 69 & PCR & $14 / 46$ & $5 / 23$ & $\begin{array}{l}0.295(P<0.0047 \\
A P O E \varepsilon 4)\end{array}$ & 237 \\
\hline Brain & 109 & PCR & $45 / 61$ & $30 / 48$ & $(P<0.0001, A P O E \varepsilon 4)$ & 238 \\
\hline Brain & 110 & PCR & $54 / 74$ & $26 / 36$ & 0.82 & 239,240 \\
\hline $\begin{array}{l}\text { Total } \\
\text { brain }\end{array}$ & 556 & & $\begin{array}{l}210 / \\
344\end{array}$ & $118 / 212$ & $\begin{array}{l}\mathrm{P}=0.2152 \mathrm{OR}=1.25 \\
\mathrm{Cl}=0.9-1.8\end{array}$ & \\
\hline $\begin{array}{l}\text { Number of } \\
\text { control cas } \\
\text { Fischer tes } \\
\text { CSF, cereb } \\
\text { hybridisati }\end{array}$ & $\begin{array}{l}\text { heimer cas } \\
\text { with positi } \\
\text { R, odds rat } \\
\text { binal fluid; } \\
\text { PCR, polyn }\end{array}$ & $\begin{array}{l}\text { with posit } \\
\text { detection/ } \\
\mathrm{Cl}, 95 \% \mathrm{c} \\
\mathrm{V}-1 \text {, herpe } \\
\text { rase chain }\end{array}$ & $\begin{array}{l}\text { detec } \\
\text { mber o } \\
\text { idence } \\
\text { simplex } \\
\text { action; }\end{array}$ & $\begin{array}{l}\text { /number of } A \\
\text { ontrol cases a } \\
\text { erval values; + } \\
\text { rus type-1; IH } \\
\text { PE ع4: epsilo }\end{array}$ & $\begin{array}{l}\text { imer cases analysed; Cor } \\
\text { sed. } P \text {, value of significar } \\
\text { sitive; -, negative; AD, Alz } \\
\text { nmunohistochemistry; IS } \\
\text { allele of apolipoprotein E. }\end{array}$ & $\begin{array}{l}\text { number of } \\
\text { lowing } \\
\text { ro disease; } \\
\text { itu }\end{array}$ \\
\hline
\end{tabular}


Anti-HSV-1 antibodies as detected in the CSF by enzyme-linked immunosorbent assay (ELISA) were also significantly higher in $\mathrm{AD}$ patients than in younger controls, but without a significant difference between the $\mathrm{AD}$ and age-matched control groups (Ref. 242). Increased titres of HSV1 IgGs, which characterise past infection, were observed in AD cases and age-matched controls, without a significant difference between the two groups (Refs 243, 244). In a large prospective study, in addition to HSV-1 IgG, the presence of IgM, which characterises active primary infection or reactivation of the infection, was also assessed in the sera of 512 elderly patients, initially free of dementia. During 14 years of follow-up, 77 $\mathrm{AD}$ cases were diagnosed. In contrast to IgG, IgM-positive subjects showed a significantly higher risk of developing $\mathrm{AD}$, indicating that reactivation of HSV-1 seropositivity is correlated with AD (Ref. 245).

Other herpes viruses were also detected in the brain using PCR: human herpes virus 6 (HHV6) types $\mathrm{A}$ and $\mathrm{B}$, herpes simplex virus type-2 (HSV-2) and cytomegalovirus (CMV). HHV6, HSV-2 and CMV were observed in 70\%, 13\% and $36 \%$ of $\mathrm{AD}$ patients and in $40 \%, 20 \%$ and $35 \%$ of controls, respectively. The differences between the groups were not statistically significant (Ref. 246).

In addition to $\mathrm{CMV}$, a possible association between HLA-BW15 and AD has also been reported (Ref. 247). A recent study revealed that elderly subjects with high levels of antibody against CMV develop more severe cognitive decline over 4 years (Ref. 248) compared with controls.

The adenovirus early region $1 \mathrm{~A}$ (E1A) gene and its expression using ISH and immunohistochemistry were analysed in five $\mathrm{AD}$ cases and in two controls. Reactive microglial cells in both $\mathrm{AD}(5 / 5)$ and control brain tissue $(2 / 2)$ showed positive hybridisation and immunoreactive expression of adenovirus E1A, indicating a monocyte- or microgliamediated entry of adenovirus into the central nervous system (CNS) (Ref. 249).

Borna disease virus (BDV) was linked to affective disorders and schizophrenia (Refs 139, 142). A few attempts have been made to analyse the prevalence of BDV antibodies and BDV p40 gene coding sequences in AD (Refs 250, 251, 252), which did not show an association (Table 3). Following Borna-virus-induced infection in $\mathrm{APP}(\mathrm{Tg} 2576)$ transgenic mice, a reduction of cortical and hippocampal $A \beta$ deposits was observed (Ref. 253). One explanation is that the stimulation and activation of microglia might produce this effect.

The human immunodeficiency virus type-1 (HIV-1) (Ref. 254) is able to induce the biological hallmarks of $\mathrm{AD}$; however, the virus is present in the brains of mostly young patients suffering from acquired immune deficiency syndrome (AIDS). The virus invades mostly macrophages and glial cells and the virus itself does not reproduce the pathological hallmarks of AD. However, by affecting immune defences, HIV-1 facilitates infection by various pathogens, including, among others, HSV-1, CMV, C. pneumoniae and spirochetes (Refs $255,256,257,258$ ).

\section{Correlates of infection risk and $A D$}

Based on the data available on the association of spirochetes, C. pneumoniae and HSV-1 with AD, contingency tables were used to analyse the strength of the association and the risk of infection in AD. In those studies where all types of spirochetes were detected using neutral techniques, spirochetes were observed in the brain in $90.1 \%(64 / 71)$ of $\mathrm{AD}$ cases and were absent in controls without any AD-type changes. This difference is significant (Table 1), and the association remains significant when cases where spirochetes were analysed in the blood are also included. The association between periodontal pathogen spirochetes and $\mathrm{AD}$ is also statistically significant. They were detected in the brain in $93.7 \%$ of $\mathrm{AD}$ cases and in $33.3 \%$ of controls. B. burgdorferi was about 13 times more frequent in $\mathrm{AD}$ cases than in controls, a statistically significant difference. It is noteworthy that $B$. burgdorferi was detected in all $\mathrm{AD}$ cases with a positive serology or where spirochetes were cultivated from the brain (Table 1). Taken together, in all studies where spirochetes or their specific species (periodontal Treponema spirochetes or $B$. burgdorferi) were detected in the brain, it can be concluded that the frequency of spirochetes is more than eight times higher in AD cases $(90 / 131 ; 68.7 \%)$ than in controls $(6 / 71 ; 8.41 \%)$. That spirochetes were cultivated from the brains of $\mathrm{AD}$ patients indicates that viable spirochetes are present in advanced stages of dementia. They can sustain persisting infection and inflammation and cause neuronal destruction (Ref. 148). 
The frequency of $C$. pneumoniae was about five times higher in $\mathrm{AD}$ cases $(60 / 125 ; 48 \%)$ than in controls $(5 / 52 ; 9.6 \%)$. The difference remains significant when those cases where $C$. pneumoniae was detected in the CSF were also included (Table 1). That C. pneumoniae was cultivated from the brain (Refs 200, 213) and CSF (Ref. 202) and that replicative RBs were present in glial cells, neurons and pericytes in $\mathrm{AD}$ indicate that this microorganism is also present in a viable, active form in the brain in AD.

There is no significant difference between the frequency of HSV-1 detected in the brain in AD patients compared with age-matched control. However, a significant difference was observed between $A P O E$ \&4-positive and -negative $\mathrm{AD}$ carriers, as reported by several authors (Refs 236, 237, 238, 259, 260), except for Beffert and colleagues (Refs 239, 240). A significant association of $\mathrm{AD}$ with ongoing or reactivated HSV-1 infection was reported (Ref. 245).

\section{Evidence for a causal role of pathogens in AD}

Additional studies have brought further evidence in favour of a probable causal relationship between spirochetes, C. pneumoniae, HSV-1 and AD. Exposure of primary mammalian neuronal and glial cells to spirochetes, namely to $B$. burgdorferi, which can be cultivated and propagated in pure culture, generated thioflavin-S-positive and $A \beta$-immunoreactive amyloid plaques and tangle- and granulovacuolar-like formations in vitro (Refs 175, 261). In situ, in the spirocheteinduced $A \beta$ plaques, synchrotron infrared microspectroscopy analysis revealed the presence of a $\beta$-pleated sheet conformation (Ref. 261). Spirochete-induced increases in $A \beta$, APP and phosphorylated tau were all detected by western blot in infected cell cultures (Ref. 261). This additional experimental evidence indicates that spirochetes are able to induce an AD-type host reaction and reproduce the defining pathological and biological hallmarks of AD (Refs 175, 261). Similar in vitro studies performed on CNS organotypic cultures, which aim to replace in vivo experiments, showed identical results (Ref. 261). Reference B. burgdorferi spirochetes (strain B31) and those cultivated from the AD brain (strains ADB1 and ADB2) invaded neurons and glial cells and induced nuclear fragmentation in vitro, indicating that the spirochetes cultivated from the brains of AD patients are invasive and cause neuronal and glial damage and apoptosis (Refs 175, 261). Spirochetes occur in both extra- and intracellular locations. They invade neurons in vitro, in primary neuronal cultures (Refs 175, 261), in the cerebral cortex and in the trigeminal ganglia of AD patients (Refs 146, 147, 148, 149, 175, 183, 184, 261). Historical observations and illustrations showing that chronic spirochetal infection can reproduce the clinical, pathological and biological hallmarks of AD strongly support a causal relationship between spirochetal infection and AD (Refs 114, 115, 124). All these observations indicate that various types of spirochetes, including B. burgdorferi and several periodontal pathogen spirochetes, in an analogous way to T. pallidum, can cause dementia, cortical atrophy and the pathological and biological hallmarks of AD.

Astrocytes and microglia infected in vitro with C. pneumoniae display inclusions that are indistinguishable from those characteristic of active infection of the standard HEp-2 host cell line (Refs 214, 215). It was reported that chronic or persistent infection of CNS cells with C. pneumoniae can affect apoptosis in $\mathrm{AD}$, in both a pro- and antiapoptotic manner (Refs 203, 214, 215). Furthermore, infection of BALB/c mice by intranasal inhalation of $C$. pneumoniae initiated $\mathrm{A} \beta_{1-42}$ deposits in the brain that resembled senile plaques (Ref. 262). Antibiotic treatment following $C$. pneumoniae infection limited the number of induced amyloid plaques in vivo (Ref. 263).

The glycoprotein B $(\mathrm{gB})$ of HSV-1 has a highly homologous sequence to a fragment of $A \beta$ (Ref. 264). Synthetic peptides derived from this region accelerate fibrillar aggregation of $A \beta$ in vitro. They can self-assemble into fibrils, which are ultrastructurally indistinguishable from $A \beta$ and are neurotoxic at a similar dose to $A \beta$. It was proposed that HSV-1 might act as a 'seed' for senile plaque formation (Ref. 265). It was also shown that HSV-1 is associated with APP during its anterograde transport, which might affect APP degradation and synaptic function (Ref. 265).

Exposure of cultured cells to HSV-1 results in increased intracellular $A \beta$ levels in neurons and glial cells as analysed by immunocytochemistry, 
ELISA and western blot. Tau phosphorylation was also observed at a number of sites that are phosphorylated in AD (Refs 266, 267, 268). It was suggested that the association of viral DNA and senile plaques is very likely to be causal, because HSV- 1 is able to increase the level of $A \beta$ in neurons of infected mice in vivo (Ref. 266).

\section{Evidence for underlying mechanisms Sources and dissemination}

Spirochetes, C. pneumoniae and HSV-1 are all able to invade the brain (Fig. 3) and generate latent and persistent chronic infection (Refs 144, 145, 146, 147, $148,149,228,229,269)$. The strong neurotropism of spirochetes is well known (Ref. 167). In addition to haematogenous dissemination, spirochetes can spread through the lymphatic system and along nerve fibre tracts (Ref. 167). Periodontal invasive spirochetes were detected in the trigeminal ganglia and along the trigeminal nerve (Ref. 147). They might also propagate along the fila olfactoria and tractus olfactorius, which would enable them to reach the CSF, the septal and hippocampal regions in the earliest stages of the disease. This would be in harmony with the olfactory hypothesis (Refs 94, 95, 96) and the early involvement of the olfactory tract and bulb (Ref. 97).

Through infected circulating monocytes, C. pneumoniae can also spread by haematogenous dissemination and, by crossing the blood-brain barrier, infect the brain. C. pneumoniae is an upper respiratory tract pathogen and can reach the brain through the olfactory system (Ref. 95). Intranasal inhalation of $C$. pneumoniae initiated plaque-like $A \beta_{1-42}$ deposits in the brain in BALB/c mice, and C. pneumoniae-specific DNA was detected by PCR in the olfactory bulb in AD (Ref. 262).

HSV-1 infection might also reach the brain through the olfactory system, by infection of cranial and peripheral nerves and their ganglia and through haematogenous dissemination (Refs 270, 271). The virus can reside in the brain

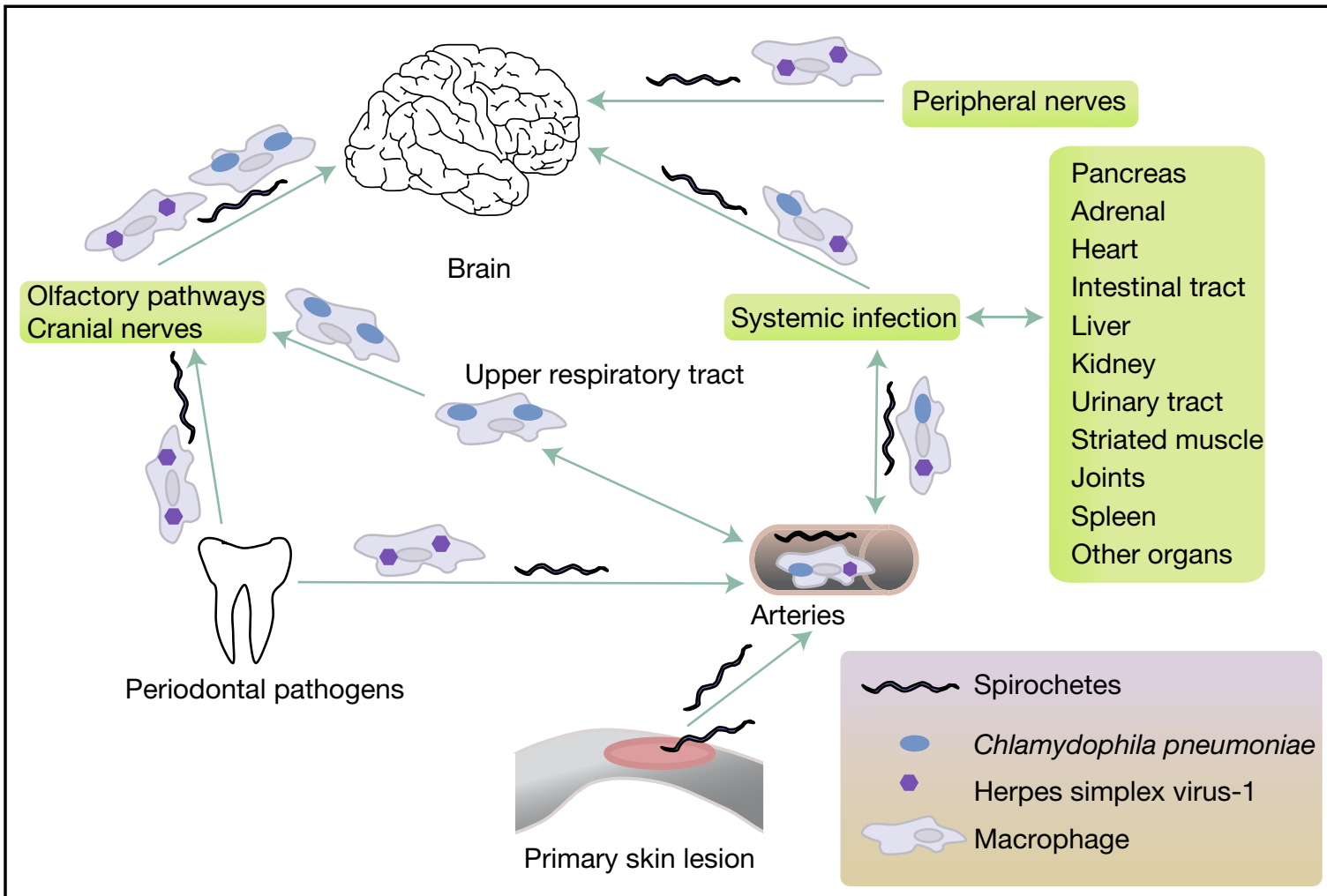

Sources and dissemination of pathogens associated with Alzheimer disease

Expert Reviews in Molecular Medicine @ 2011 Cambridge University Press

Figure 3. Sources and dissemination of pathogens associated with Alzheimer disease. 
in a latent form and be reactivated by peripheral infection, stress or immunosuppression (Ref. 268).

\section{Neuroinflammation and TLR signalling}

Persisting, poorly degradable bacterial remnants in mammalian tissues act as chronic inflammatory stimuli (Refs 272, 273, 274). Lipopolysaccharides (LPSs), PGN and various bacterial lipoproteins elicit a variety of proinflammatory responses and might represent an important source of inflammation in AD. Complex interactions between the innate and adaptive immune systems have a major role in infection (Ref. 275). The functions of innate immunity allow host cells to recognise most microorganisms, execute proinflammatory defences and start adaptive immune responses.

Bacteria attach to host cells through a variety of cell-surface components, including surface amyloid proteins, which interact with host proteases (Refs 276, 277, 278, 279, 280, 281, 282, 283). Proteolysis of the extracellular matrix allows bacteria to penetrate the basement membrane and invade host cells.

It is the innate immune system that provides the first line of defence against microorganisms. Pattern recognition receptors (PRRs), such as Toll-like receptors (TLRs), recognise unique structures of invading microorganisms (Ref. 284). Patients with genetic defects related to signalling pathways activated by TLRs frequently suffer from severe recurrent infection (Refs 285, 286, 287, 288, 289). In the absence of TLRs, death from experimental sepsis is significantly enhanced (Ref. 287). Various bacteria, including spirochetes, activate TLR signalling and interact with CD14 (Refs 290, 291, 292). T. pallidum and B. burgdorferi or their synthetic membrane lipoproteins are major inflammatory mediators (Refs 293, 294) and activate both the classical and alternative complement pathways, which opsonise and kill pathogens without the need for antibody.

Complex interactions between pathogenassociated molecular patterns (PAMPs), PRRs and TLR signalling pathways have a major role in linking innate and adaptive immunity and maintaining pathogen-free host tissues (Ref. 275). TLRs activate two major signalling pathways (Fig. 4). The core pathway activated by most TLRs leads to the activation of transcription factor nuclear factor-kappa B (NF$\kappa \mathrm{B})$ and the mitogen-activated protein kinases
(MAPKs) p38 and Jun kinase (JNK). The second pathway is activated by TLR3 and TLR4 and results in the activation of both NF- $\mathrm{kB}$ and interferon regulatory factor-3 (IRF3), allowing the induction of another set of inflammatory genes, including the antiviral interferon- $\beta$ gene (IFNB).

Activation of p38 MAPKs during bacterial infection was also shown to be crucial in the local production of cytokines such as IL-8 (Ref. 295) and in the development of effective immune responses in vivo (Ref. 296). Toxininduced p38 MAPK activation requires pore formation and is inhibited by the relief of osmotic stress.

Pore-forming toxins are the most common class of bacterial protein toxins and are often important virulence factors (Ref. 297). Pore-forming bacterial toxins are typically oligomers of soluble, monomeric proteins or peptides, which form transmembrane channels. Channel formation in the membrane of targeted cells, which triggers cellular ion imbalance, is a widely used form of bacterial attack (Refs 298, 299). These poreforming bacterial toxins generate calciumdependent and lipid-mediated signalling on host cell surfaces, leading to a variety of events such as tyrosine phosphorylation (Ref. 300), actin rearrangement (Ref. 301), NF- $\kappa \mathrm{B}$ activation (Ref. 302) and regulation of gene expression through histone modification (Ref. 303).

Mammals also use bacterial porin-like proteins such as perforins as part of their innate immune defences (Ref. 304). A $\beta_{1-42}$ was shown to be an AMP that belongs to the innate immune system. Toxic oligomers of $A \beta_{1-42}$ bind to lipid bilayers of bacterial membranes and enveloped viruses, triggering $\mathrm{Ca}^{2+}$ influx and bacteriolysis or viral destruction. Deregulation of the balance between host cell destruction by pathogens and pathogen destruction by the host immune systems will influence the outcome of infections.

The innate and alternative pathways through the common membrane attack complex (MAC, C5b9) cause bacteriolysis (Refs 305, 306, 307). Cellular and humoral components of the immune system reactions are both associated with AD (Refs 98, 99, 100, 101, 102). The adaptive immune system kills pathogens through the formation of specific antibodies directed against invading microorganisms. Monocytes, macrophages and microglia 


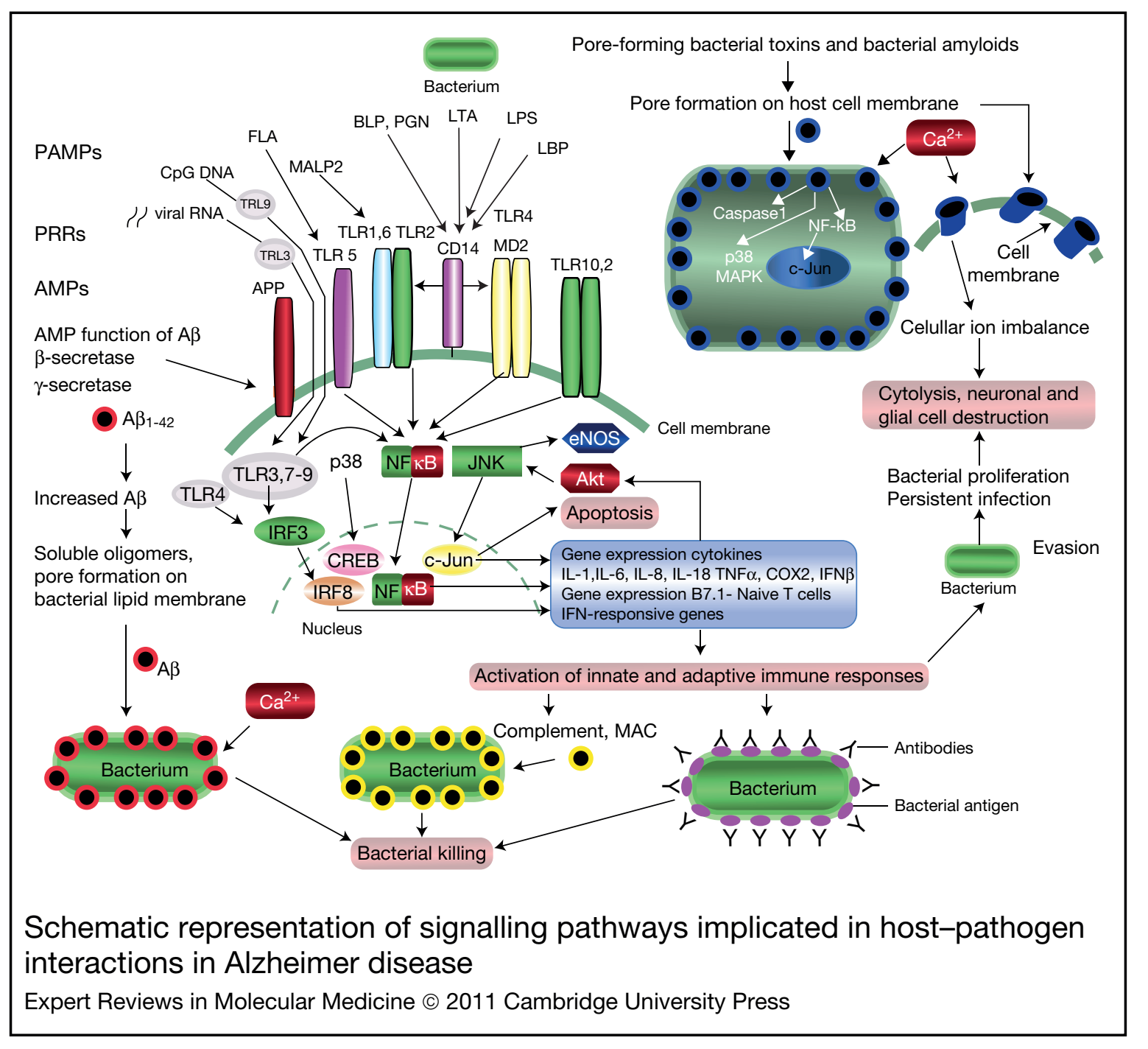

Figure 4. Schematic representation of signalling pathways implicated in host-pathogen interactions in Alzheimer disease. Pattern recognition receptors (PRRs) recognise conserved structural components of microorganisms, called pathogen-associated molecular patterns (PAMPs) or ligands, which include peptidoglycan (PGN), lipoteichoic acid (LTA), flagellin (FLA), bacterial lipoprotein (BLP) and nucleic acid structures, such as bacterial CpG DNA or viral RNA, unique to bacteria and viruses. Lipopolysaccharide (LPS) is recognised following its binding to lipoprotein binding protein (LBP). Only Toll-like receptors (TLRs) have a cytoplasmic domain for signal transduction. Plasma-membrane-localised TLRs include TLR1, TLR2, TLR4, TLR5, TLR6 and TLR10, whereas endosomal TLRs include TLR3, TLR7, TLR8 and TLR9. TLR9 is responsible for the recognition of CpG islands of bacterial DNA. Complex interactions between pathogenassociated molecular patterns (PAMPs), pattern recognition receptors (PRRs) and TLR signalling pathways have a major role in linking innate and adaptive immunity and maintaining pathogen-free host tissues. Mammals use antimicrobial peptides (AMPs) as part of their innate immune defences to destroy invading pathogens. In contrast, in a similar way, pore-forming bacterial surface proteins are also able to destroy host cells. Evasion of pathogens from destruction by the host immune defences will result in chronic persistent infection and host cell destruction. APP, amyloid precursor protein; A $\beta$, amyloid beta; CD14, cluster of differentiation 14; NF-KB, nuclear factor-kappa B; MALP2, mycoplasma diacylated lipopeptide 2; p38 MAPK, mitogen-activated protein kinase; JNK, c-Jun kinase; MAC, membrane attack complex; MD2, lymphocyte antigen 96; Akt, serine/threonine protein kinase Akt1; IRF, interferon regulatory factor; IL, interleukin; TNF, tumour necrosis factor; COX2, cyclooxygenase 2; IFN, interferon, CREB, CAMP response element binding. 
participate in both the innate and adaptive immune responses. When activated, they secrete chemokines and cytokines and express various proinflammatory molecules needed for the efficient removal of pathogens and damaged cells.

Neuroinflammatory responses that include activation of glia with marked elevation of cytokine expression, in particular elevation of IL-1, are observed in AD, in Down syndrome fetuses and children before plaque formation, and also in HIV infection (Refs 99, 308, 309). IL1 directs both the in vivo (Ref. 310) and in vitro synthesis of APP (Ref. 311), thus favouring senile plaque formation in AD. IL-1 upregulation of ApoE promotes ApoE-mediated induction of APP (Ref. 312) and MAPK-p38mediated tau phosphorylation, in part by upregulation of MAPK-p38 synthesis and activation and by favouring the formation of neurofibrillary tangles (Refs 313, 314, 315). IL-1 also influences neurotransmission because it increases the synthesis and activation of AChE (Ref. 316) and induces neuron loss by increasing caspase 1 (IL-1 $\beta$ cleavage enzyme) activity (Refs 317, 318). Microglial activation by APP and release of secreted APP (sAPP) modulated by apolipoprotein $\mathrm{E}$ also have an important role in the degenerative process of AD (Refs 313, 319). Activation of microglia with TLR2, TLR4 and TLR9 ligands increases $A \beta$ ingestion in vitro (Ref. 320). Furthermore, stimulation of the immune system through TLR9 in APP transgenic (Tg2576) mice reduces $A \beta$ deposition (Ref. 321).

\section{Evasion and establishment of latent and chronic infection}

The ability of spirochetes and C. pneumoniae to evade destruction by host immune systems and establish chronic infection is well known. HSV-1 can also remain in a latent state and persist throughout life in human tissues. In the latent state, the viral genome is present, but no viral particles are produced. Viral gene expression during latency is limited to one locus - the gene encoding the latency-associated transcript (Ref. 151).

Pathogens use a broad range of strategies to overcome antigenic recognition, complement lysis and phagocytosis. Blockade of the complement cascade or acquisition of hostderived complement inhibitors results in their evasion from complement lysis. This allows microbial survival and proliferation even in immune-competent hosts. Complement-resistant strains of B. burgdorferi possess five complement regulatory acquiring surface proteins, which bind host complement inhibitors (Refs 307, 322) and a CD59-like molecule (Refs 322, 323). A fragment of HSV-1 glycoprotein C (gC) shares sequence similarity with host complement receptor 1 (CR1), showing that viruses can also escape from attack by the MAC. Bacteria and viruses protect themselves from destruction by the host adaptive immune system. B. burgdorferi induces IL-12, a cytokine recently recognised to be critical for driving cellular responses towards the Th1 subset of $\mathrm{T}$ helper cells (Refs 293, 324). This shift retards antibody induction by Th2 cells against bacteria. These various ways of evasion allow bacteria to survive and proliferate in host tissues and sustain chronic infection.

\section{Iron and nitric oxide}

Bacterial cell wall components, including LPSs and PGNs, are highly resistant to degradation by mammalian enzymes and persist indefinitely in mammalian tissues. During chronic exposure, bacteria and bacterial debris accumulate in infected host tissues, sustaining chronic inflammation and slowly progressive cell damage (Refs 272, 273, 274, 325, 326). Bacteria, LPSs and PGNs have a variety of biological actions in mammals (Ref. 327). They not only are inflammatory cytokine inducers and activators of complement pathways, but they also affect vascular permeability (Ref. 328), induce nitric oxide and free radicals, inhibit DNA synthesis, and cause apoptosis and cellular damage (Ref. 329).

Macrophage regulation of immune surveillance involves iron depletion (Refs 330, 331, 332). Lactoferrin, which is similar in structure to transferrin, has a role in natural defence mechanisms in mammals and is upregulated in neurodegenerative disorders. Lactoferrin exerts its anti-inflammatory action by inhibiting hydroxyl radical formation. This antioxidant property prevents DNA damage (Ref. 329). By contrast, free iron abolishes the bactericidal effects of serum and strongly enhances infection and bacterial virulence (Refs 329, 330, 331, 332). Iron has been shown to increase the formation of reactive oxygen intermediates, resulting in 
lipid peroxidation and subsequent oxidative damage of proteins and nucleic acids (Refs 330, 331, 332). By affecting T-cell generation, iron also influences antigen-specific cellular responses, T-cell functions and the production of proinflammatory cytokines by macrophages (Ref. 333). Iron, which has a fundamental role in infection, also accumulates in senile plaques in AD (Refs 330, 334, 335, 336).

Activation of macrophages and other host cells by bacteria or LPS causes inducible nitric oxide synthase (iNOS) synthesis, which in turn generates substantial amounts of nitric oxide from the amino acid L-arginine (Ref. 332). Nitric oxide is a critical component in the clearance of bacterial, viral, fungal and parasitic infections (Ref. 337). In a mouse model, genetic disruption of iNOS was associated with a significantly higher risk of dissemination and mortality of infection (Ref. 338). Pathogens have also evolved a broad array of strategies to limit nitric oxide production (Refs 338, 339, 340), which might contribute to their evasion from host immune responses (Ref. 340). Nitric oxide also has a central role in chronic degenerative diseases, including AD (Ref. 341).

\section{Amyloidogenesis}

Amyloidogenesis is the aggregation of soluble proteins into detergent-insoluble filamentous structures about $10 \mathrm{~nm}$ wide and $0.1-10 \mu \mathrm{m}$ long. These amyloid fibrils have distinct biochemical and biophysical properties, including resistance to proteinase $\mathrm{K}$ treatment, $\beta$-sheet structure and affinity for binding thioflavin S and Congo Red.

Chronic bacterial infections (e.g. rheumatoid arthritis, leprosy, tuberculosis, syphilis, osteomyelitis) are frequently associated with amyloid deposition. Cortical and vascular amyloid deposition in the atrophic form of general paresis, caused by a spirochete (T. pallidum), as in $\mathrm{AD}$, corresponds to $\mathrm{A} \beta$.

On the basis of previous observations, it has been suggested that amyloidogenic proteins might be an integral part of spirochetes and can contribute to $\mathrm{A} \beta$ deposition in $\mathrm{AD}$ (Ref. 146). It was shown that the $\mathrm{BH}(9-10)$ peptide on a $\beta$ hairpin segment of B. burgdorferi OspA forms amyloid fibrils in vitro that are similar to those in human amyloidosis (Ref. 342). Recent observations indicate that amyloid proteins constitute a previously overlooked integral part of the cellular envelope of many bacteria (Refs 343, 344, 345, 346). Amyloid fibril formation not only results in toxic aggregates, but also provides biologically functional molecules (Refs 343, 344, 347). Bacterial amyloids are involved in bacterial cell-cell interactions, in their attachment to inert solid surfaces, and in spore and biofilm formation (Ref. 347). Microbial amyloids, through interaction with host proteases, also contribute to bacterial virulence, to colonisation of the host and to invasion of host cells.

Bacterial LPSs and PGNs are used worldwide to generate in vitro and in vivo experimental inflammation and amyloidosis (Ref. 348). LPSs induce $A \beta$ accumulation, increased APP levels and hyperphosphorylation of tau in vitro and in vivo (Refs 261, 349, 350, 351). Increased APP mRNA in response to LPS was also detected in the basal forebrain and hippocampus of the rat (Ref. 349). A $\beta$ deposition occurs in the brains of rats chronically infused with LPSs (Ref. 349). In a triple-transgenic mouse model of $\mathrm{AD}$, repeated challenges with LPSs were shown to exacerbate CNS inflammation and to cause increased tau phosphorylation (Ref. 351).

\section{Genetic factors}

Host responses to bacterial infections are genetically controlled. Promoter polymorphisms in the genes of proinflammatory cytokines are associated with susceptibility to infection (Ref. 352). Tumour necrosis factor alpha (TNF- $\alpha$ ) is a critical mediator of host defence against infection. Polymorphisms in the gene encoding TNF- $\alpha$ might determine a strong cell-mediated immune response or a weak or absent cellular response, which reflects the genetic variability in cytokine production (Refs 352, 353). In the absence of cell-mediated immune responses, the microorganism can spread freely and accumulate in infected host tissues (Ref. 354). Accordingly, in Mycobacterium leprae infection, two distinct phenotypes can be distinguished: tuberculoid leprosy and the lepromatous leprosy. In the tuberculoid or paucibacillary form, there is strong inflammatory infiltration and the number of microorganisms is low. Conversely, in the lepromatous or bacillary form, the inflammatory infiltrates are poor or absent and the number of M. leprae is high. A similar polarity in host reactions - the infiltrative form with strong cell-mediated 
immune responses and few spirochetes versus the atrophic form, lacking lymphoplasmocytic infiltrates but with numerous spirochetes occurs in response to $T$. pallidum and $B$. burgdorferi infection (Refs 114, 115, 118, 149). The influence of TNF- $\alpha$ polymorphism on spirochetal infections has also been demonstrated by others (Refs 355).

Class II major histocompatibility genes influence host immune responses to bacterial and viral infections. The major histocompatibility complex phenotype of the antigen-presenting cell can modulate Th1-like versus Th2-like cell activity against $M$. leprae and other pathogens. In general, it has been acknowledged that human leukocyte antigen (HLA) DR isotypes are associated with a protective response, whereas DQ isotypes are associated with the multibacillary lepromatous form with a limited cellular response. HLA gene polymorphism is a dominant marker of susceptibility to various infections, including $B$. burgdorferi infection (Ref. 356). The important role of the HLA system in controlling cellmediated responses suggests that differences in HLA haplotypes could contribute to the wide spectrum of immune responses observed in leprosy and in other infections (Ref. 357). It is noteworthy that TNF- $\alpha$ and HLA polymorphisms, which are risk factors for infection, substantially influence the risk of $\mathrm{AD}$ (Refs 61, 358, 359, 360, 361, 362).

Association between AD pathology and IL-1 $\beta$ expression patterns (Ref. 363), and between disease risk and IL-1 $\beta$ gene polymorphisms, has been reported (Refs 62, 364). Genetic variation in the expression of microbial PRRs, including TLRs, and CD14 gene polymorphisms predispose to various infections and are also associated with AD (Refs 365, 366).

Genetic mutations in APP, PS1 and PS2 are related to the processing of APP (Ref. 39). Because APP has an important role in the regulation of immune system reactions and in Tcell differentiation (Refs 16, 17, 18), genetic defects in such genes should also result in increased susceptibility to infection.

$A P O E \quad \varepsilon 4$ enhances the expression of inflammatory mediators (Refs 367, 368) and has a modulatory function in susceptibility to infection by various bacteria, viruses and protozoa (Refs 367, 368, 369, 370, 371, 372). $A P O E$ genotyping of three AD cases, where $B$. burgdorferi was detected and cultivated from the brain, showed that two of them were APOE $\varepsilon 4$ carriers. The low number of cases does not allow any conclusion for an eventual link between spirochetal infection and the APOE \&4 allele (Ref. 149). Sixty-four per cent of AD cases with positive $C$. pneumoniae PCR had at least one APOE $\varepsilon 4$ allele (Ref. 207). ISH and quantitative real-time PCR analyses indicated that the number of $C$. pneumoniae-infected cells and the bacterial load in affected brain regions of $A P O E$ \&4 carriers in $\mathrm{AD}$ were significantly higher compared with those lacking that allele (Ref. 200). Furthermore, HIV-1-infected subjects carrying the APOE $\varepsilon 4$ allele have higher recorded levels of dementia (Ref. 369), and the $\varepsilon 4$ allele has also been shown to modulate HSV1 infection (Refs 240, 259, 260, 371).

\section{Outstanding research questions and conclusions}

The analysis of all positive and negative data available in the literature on the association of pathogens with $\mathrm{AD}$ indicates a statistically significant association between various types of spirochetes, C. pneumoniae and AD. There is no significant difference between the frequency of HSV-1 in AD cases compared with age-matched controls. However, several authors found a significant difference between the frequencies of HSV-1 in APOE \&4 carriers and noncarriers. The occurrence of positive anti-HSV-1 IgM was reported to be a risk factor for $\mathrm{AD}$ (for a recent review, see Ref. 373).

Lesions that are similar to senile plaques, neurofibrillary tangles and neuropil threads, and granulovacuolar degeneration, accumulation of $\mathrm{A} \beta$, increased APP levels and phosphorylation of tau have all been induced by exposure of mammalian neuronal and glial cells and CNS organotypic cultures to spirochetes. A $\beta$-positive plaques were induced by inhalation of $C$. pneumoniae in mice in vivo, and exposure to HSV-1 increased the A $\beta$ level and produced tau phosphorylation in neurons in vitro and in vivo.

Through TLRs and other PRRs, pathogens or their toxic components induce gene expression and activation of proinflammatory molecules by host cells. Both the classical and alternative complement pathways are activated in AD. MAC(C5b-9), which is intended to lyse bacteria or encapsulated viruses, and activated microglia that are designed to clean up debris and foreign 
bacteria are both associated with cortical $\mathrm{AD}$ lesions.

Evasion of pathogens from host defence reactions results in sustained infection and inflammation. The microorganisms and their toxic components can be observed in affected brains, along with host immunological responses.

Spirochetes, C. pneumoniae and HSV-1 disseminate from the primary site of infection to the brain usually through systemic infection. As in syphilis, systemic infection and inflammation precede the development of dementia by years or decades. Detection of infection in its early, peripheral stage can hamper its dissemination to the CNS and prevent dementia. Consequently, peripheral infections can have a role in the initiation and progression of neurodegeneration in $\mathrm{AD}$ (Refs 146, 374, 375, 376). Worsening of peripheral and systemic infection will deteriorate CNS involvement. One example is periodontitis, which is caused mostly by Gramnegative bacteria, including periodontal spirochetes, which represents a risk factor for AD (Refs 156, 377).

It is important to consider that several types of spirochetes and several types of pathogens can occur in AD. Coinfection of B. burgdorferi with various periodontal spirochetes (Ref. 147) or with T. pallidum (Ref. 378) is well documented. $T$. pallidum frequently coinfects with other bacteria and herpes viruses in syphilis (Ref. 167). In Lyme disease, coinfection of B. burgdorferi with $C$. pneumoniae and HSV-1, which are also associated with $\mathrm{AD}$, can be observed. Coinfection by several microorganisms can accelerate the degenerative process, exacerbate CNS damage and worsen dementia.

An infectious origin of AD is in harmony with recent observations showing that $A \beta$ belongs to the group of AMPs, which are potent, broadspectrum bactericides targeting Gram-negative and Gram-positive bacteria, enveloped viruses, fungi and protozoans (Ref. 31). A $\beta$ has the capacity to associate with lipid bilayers of bacterial cell membranes and to exert antimicrobial activity by membrane permeabilisation and by alteration of calcium homeostasis (Refs 31, 379). The microtubulebinding site of tau protein also exhibits antimicrobial properties (Ref. 380).

Inflammation has a primordial role in the elimination of invading pathogens and infected host cells. If infection is eradicated, it helps the healing process. Some proinflammatory molecules, such as cytokine IL-1 $\beta$, in addition to their harmful effects, have a beneficial and protective effect (Ref. 381). Therefore, long-term use of anti-inflammatory drugs alone might weaken the elimination of pathogens and facilitate their evasion, survival and slowly progressive proliferation. Combined antibiotic, antiviral and anti-inflammatory therapy is suggested as the treatment of choice.

In conclusion, the data available indicate that infectious agents can initiate the degenerative process in $\mathrm{AD}$, sustain chronic inflammation, and lead to progressive neuronal damage and amyloid deposition. The accumulated knowledge, views and hypotheses proposed to explain the pathogenesis of AD fit well with an infectious origin of the disease. The outcome of infection is determined by the genetic predisposition of the patient, by the virulence and biology of the infecting agent, and by various environmental factors, such as exercise, stress and nutrition.

More attention and support is needed for this emerging field of research. Infection starts long before the manifestation of dementia; therefore, an adequate treatment should start early. Because antibacterial, antiviral and anti-inflammatory therapy is available, as in syphilis, one could prevent and eradicate dementia. The effect on the suffering of patients and on the reduction of healthcare costs would be considerable.

\section{Acknowledgements and funding}

I am grateful to all those colleagues and friends who strongly supported my work on this emerging field of research during the last two decades. They all contributed, in different ways, to the realisation of this work. I thank B. Balin, A. Hudson, J. Hudson and R. Itzhaki, who have reviewed and completed data related to their field of research on C. pneumoniae and HSV-1, and R. Kraftsik for his help with the statistical analysis. This work was funded by the Prevention Alzheimer International Foundation, Switzerland. I am grateful to the peer reviewers and to the editors of the journal, who significantly contributed with their constructive advice and remarks.

\section{References}

1 Alzheimer, A. (1907) Über eine eigenartige Erkrankung der Hirnrinde. Allgemeine Zeitschrift 
für Psychiatrie und Psychisch-Gerichtliche Medicin 64, 146-148

2 Alzheimer, A. (1911) Über eigenartige Krankheitsfälle des späteren Alters. Zeitschrift für die gesamte Neurologie und Psychiatrie 4, 356-385

3 Katzman, R. (1976) The prevalence and malignancy of Alzheimer's disease: a major killer. Archives of Neurology 33, 217-218

4 Terry, R.D. and Davies, P. (1980) Dementia of the Alzheimer type. Annual Review of Neuroscience 3, 77-95

5 Blocq, P. and Marinesco, G. (1892) Sur les lésions et la pathogénie de l'épilepsie dite essentielle. Semaine Médicale 12, 445-446

6 Redlich, E. (1898) Über miliare Sklerose der Hirnrinde bei seniler Atrophie. Jahrbuch für Psychiatrie und Neurologie 17, 208-216

7 Gallyas, F. (1971) Silver staining of Alzheimer's neurofibrillary changes by means of physical development. Acta Morpholpgica-Academiae Scientiarum Hungaricae 19, 1-8

8 Simchowicz, T. (1911) Histologische Studien über die senile Demenz. Histologie Und Histopathologie Arb über Grosshirnrinde 4, 367-444

9 Terry, R.D. et al. (1991) Physical basis of cognitive alterations in Alzheimer's disease: synapse loss is the major correlate of cognitive impairment. Annals of Neurology 30, 572-580

10 Kang, J. et al. (1987) The precursor of Alzheimer's disease amyloid A4 protein resembles a cell-surface receptor. Nature 325, 733-736

11 Selkoe, D.J. (1998) The cell biology of beta-amyloid precursor protein and presenilin in Alzheimer's disease. Trends in Cell Biology 8, 447-453

12 Glenner, G.G. and Wong, C.W. (1984) Alzheimer's disease: initial report of the purification and characterization of a novel cerebrovascular amyloid protein. Biochemical and Biophysical Research Communications 120, 885-890

13 Schubert, D. et al. (1988) Amyloid beta protein precursor is possibly a heparan sulfate proteoglycan core protein. Science 241, 1759-1763

14 Bush, A.I., Beyreuther, K. and Masters, C.L. (1993) The beta A4 amyloid protein precursor in human circulation. Annals of the New York Academy of Sciences 695, 175-182

$15 \mathrm{Li}$, Q.X. et al. (1999) The amyloid precursor protein of Alzheimer disease in human brain and blood 66, 567-574

16 Allen, J.S. et al. (1991) Alzheimer's disease: betaamyloid precursor protein mRNA expression in mononuclear blood cells. Neuroscience Letters 132, 109-112
17 Mönning, U. et al. (1990) Synthesis and secretion of Alzheimer amyloid beta A4 precursor protein by stimulated human peripheral blood leucocytes. FEBS Letters 277, 261-266

18 Ledoux, S. et al. (1993) Amyloid precursor protein in peripheral mononuclear cells is up-regulated with cell activation. Journal of Immunology 150, 5566-5575

19 Jarrett, J.T. and Lansbury, P.T. (1992) Amyloid fibril formation requires a chemically discriminating nucleation event: studies of an amyloidogenic sequence from the bacterial protein OsmB. Biochemistry 31, 12345-12352

20 Kim, W. and Hecht, M.H. (2005) Sequence determinants of enhanced amyloidogenicity of Alzheimer A\{beta\}42 peptide relative to A $\{$ beta 4 40. Journal of Biological Chemistry 280, 35069-35076

21 Lambert, M.P. et al. (1998) Diffusible, nonfibrillar ligands derived from Abeta1-42 are potent central nervous system neurotoxins. Proceedings of the National Academy of Sciences of the United States of America 95, 6448-6453

22 Hartley, D.M. et al. (1999) Protofibrillar intermediates of amyloid beta-protein induce acute electrophysiological changes and progressive neurotoxicity in cortical neurons. Journal of Neuroscience 19, 8876-8884

23 Walsh, D.M. et al. (2002) Naturally secreted oligomers of amyloid beta protein potently inhibit hippocampal long-term potentiation in vivo. Nature 416, 535-539

24 Kirkitadze, M.D., Bitan, G. and Teplow, D.B. (2002) Paradigm shifts in Alzheimer's disease and other neurodegenerative disorders: the emerging role of oligomeric assemblies. Journal of Neuroscience Research 69, 567-577

25 Cerf, E. et al. (2009) Antiparallel beta-sheet: a signature structure of the oligomeric amyloid beta- peptide. Biochemical Journal 421, 415-423

26 Pitt, J. et al. (2009) Alzheimer's-associated Abeta oligomers show altered structure, immunoreactivity and synaptotoxicity with low doses of oleocanthal. Toxicology and Applied Pharmacology 240, 189-197

27 Lashuel, H.A. et al. (2002) Neurodegenerative disease: amyloid pores from pathogenic mutations. Nature 418, 291

28 Rudel, T. et al. (1996) Modulation of Neisseria porin (PorB) by cytosolic ATP/GTP of target cells: parallels between pathogen accommodation and mitochondrial endosymbiosis. Cell 85, 391-402 
29 Ayala, P. et al. (2005) The pilus and porin of Neisseria gonorrhoeae cooperatively induce $\mathrm{Ca}(2+)$ transients in infected epithelial cells. Cellular Microbiology 7, 1736-1748

30 Müller, A. et al. (1999) Neisserial porin (PorB) causes rapid calcium influx in target cells and induces apoptosis by the activation of cysteine proteases. EMBO Journal 18, 339-352

31 Soscia, S.J. et al. (2010) The Alzheimer's diseaseassociated amyloid beta-protein is an antimicrobial peptide. PLoS One 5, e9505

32 Kidd, M. (1963) Paired helical filaments in electron microscopy of Akzheimer's disease. Nature 197, 192-193

33 Terry, R.D. (1963) The fine structure of neurofibrillary tangles in Alzheimer's disease. Journal of Neuropathology and Experimental Neurology 22, 629-642

34 Goedert, M., Trojanowski, J.Q. and Lee, V.M.-Y. (1996) The neurofibrillary pathology of Alzheimer's disease. In The molecular and genetic basis of neurological disease. (2nd edn) (Rosenberg R.N., et al., eds), Butterworth-Heinemann, Stoneham, MA.

35 Lee, V.M.-Y. (1995) Disruption of the cytoskeleton in Alzheimer's disease. Current Opinion in Neurobiology 5, 663-668

$36 \mathrm{Lu}$, P.J. et al. (1999) The prolyl isomerase Pin1 restores the function of Alzheimer-associated phosphorylated tau protein. Nature 399, 784-788

37 Sherrington, R. et al. (1995) Cloning of a gene bearing missense mutations in early-onset familial Alzheimer's disease. Nature 375, 754-760

38 Selkoe, D.J. (1996) Amyloid beta-protein and the genetics of Alzheimer's disease. Journal of Biological Chemistry 271, 18295-18298

39 Hardy, J. (1997) The Alzheimer family of diseases: many etiologies, one pathogenesis? Proceedings of the National Academy of Sciences of the United States of America 94, 2095-2097

40 Tanzi, R.E. and Bertram, L. (2001) New frontiers in Alzheimer's disease genetics. Neuron 32, 181-184

41 Hardy, J. and Selkoe, D.J. (2002) The amyloid hypothesis of Alzheimer's disease: progress and problems on the road to therapeutics. Science 297, 353-356

42 Bertram, L. and Tanzi, R.E. (2005) The genetic epidemiology of neurodegenerative disease. Journal of Clinical Investigation 115, 1449-1457

43 Nagy, Z. (2005) The last neuronal division: a unifying hypothesis for the pathogenesis of Alzheimer's disease. Journal of Cellular and Molecular Medicine 9, 531-541
44 Schellenberg, G.D. (1995) Genetic dissection of Alzheimer disease, a heterogeneous disorder. Proceedings of the National Academy of Sciences of the United States of America 92, 8552-8559

45 Goate, A. (1991) Segregation of a missense mutation in the amyloid precursor protein gene with familial Alzheimer's disease. Nature 349, 704-706

46 Mullan, M. et al. (1992) A pathogenic mutation for probable Alzheimer's disease in the APP gene at the $\mathrm{N}$-terminus of beta-amyloid. Nature Genetics 1, 345-347

47 Alzheimer's Disease Collaborative Group (1995) The structure of the presenilin 1 (S182) gene and identification of six novel mutations in early onset AD families. Alzheimer's Disease Collaborative Group. Nature Genetics 11, 219-222

48 Wasco, W. et al. (1995) Familial Alzheimer's chromosome 14 mutations. Nature Medicine 1, 848

49 Perez-Tur, J. et al. (1995) A mutation in Alzheimer's disease destroying a splice acceptor site in the presenilin-1 gene. Neuroreport 7, 297-301

50 Miklossy, J. et al. (2003) Two novel presenilin-1 mutations (Y256S and Q222H) are associated with early-on set Alzheimer's disease. Neurobiology of Aging 24, 655-662

51 Levy-Lahad, E. et al. (1995) Candidate gene for the chromosome 1 familial Alzheimer's disease locus. Science 269, 973-977

52 Citron, M. et al. (1992) Mutation of the beta-amyloid precursor protein in familial Alzheimer's disease increases beta-protein production. Nature 360, 672-674

53 Cai, X.D., Golde, T.E. and Younkin, S.G. (1993) Release of excess amyloid beta protein from a mutant amyloid beta protein precursor. Science 259, 514-516

54 Suzuki, N. et al. (1994) An increased percentage of long amyloid beta protein secreted by familial amyloid beta protein precursor (beta APP717) mutants. Science 264, 1336-1340

55 Duff, K. et al. (1996) Increased amyloid-beta42(43) in brains of mice expressing mutant presenilin 1 . Nature 383, 710-713

56 Scheuner, D. et al. (1996) Secreted amyloid betaprotein similar to that in the senile plaques of Alzheimer's disease is increased in vivo by the presenilin 1 and 2 and APP mutations linked to familial Alzheimer's disease. Nature Medicine 2, 864-870

57 Borchelt, D.R. et al. (1996) Familial Alzheimer's disease-linked presenilin 1 variants elevate Abeta1- 
42/1-40 ratio in vitro and in vivo. Neuron 17 , 1005-1013

58 Tomita, T. et al. (1997) The presenilin 2 mutation (N141I) linked to familial Alzheimer disease (Volga German families) increases the secretion of amyloid beta protein ending at the 42nd (or 43rd) residue. Proceedings of the National Academy of Sciences of the United States of America 94, 2025-2030

59 Citron, M. et al. (1997) Mutant presenilins of Alzheimer's disease increase production of 42-residue amyloid beta-protein in both transfected cells and transgenic mice. Nature Medicine 3, 67-72

60 Roses, A.D. (1994) Apolipoprotein E is a relevant susceptibility gene that affects the rate of expression of Alzheimer's disease. Neurobiology of Aging 2 (Suppl), 165-167

61 McGeer, P.L. and McGeer, E.G. (2001)

Polymorphisms in inflammatory genes and the risk of Alzheimer disease. Archives of Neurology 58, 1790-1792

62 Bertram, L. et al. (2007) Systematic meta-analyses of Alzheimer disease genetic association studies: the AlzGene database. Nature Genetics 39, 17-23

63 Guo, J. et al. (2006) A-beta and tau form soluble complexes that may promote self aggregation of both into the insoluble forms observed in Alzheimer disease. Proceedings of the National Academy of Sciences of the United States of America 103, 1953-1958

64 Perry, G. et al. (1993) Immunocytochemical evidence that the beta-protein precursor is an integral component of neurofibrillary tangles of Alzheimer's disease. American Journal of Pathology 143, 1586-1593

65 Davies, P., Katzman, R. and Terry, R.D. (1980) Reduced somatostatin-like immunoreactivity in cerebral cortex from cases of Alzheimer disease and Alzheimer senile dementa. Nature 288, 279-280

66 Perry, E.K. et al. (1981) Neurochemical activities in human temporal lobe related to aging and Alzheimer-type changes. Neurobiology of Aging 2, 251-256

67 Rossor, M.N. (1982) Neurotransmitters and CNS disease. Dementia. Lancet 2, 1200-1204

68 Fowler, C.J. et al. (1992) Neurotransmitter, receptor and signal transduction disturbances in Alzheimer's disease. Acta Neurologica Scandinavica 139 (Suppl), 59-62

69 Davies, P. and Maloney, A.J. (1976) Selective loss of central cholinergic neurons in Alzheimer's disease. Lancet 2, 1403
70 Bartus, R.T. et al. (1985) The cholinergic hypothesis: a historical overview, current perspective, and future directions. Annals of the New York Academy of Sciences 444, 332-358

71 Martins, R.N. et al. (1986) Increased cerebral glucose-6-phosphate dehydrogenase activity in Alzheimer's disease may reflect oxidative stress. Journal of Neurochemistry 46, 1042-1045

72 Pappolla, M.A. et al. (1996) The heat shock/ oxidative stress connection. Relevance to Alzheimer disease. Molecular and Chemical Neuropathology 28, 21-34

73 Smith, M.A. et al. (1994) Advanced Maillard reaction end products, free radicals, and protein oxidation in Alzheimer's disease. Annals of the New York Academy of Sciences 738, 447-454

74 Nunomura, A. et al. (2006) Involvement of oxidative stress in Alzheimer disease. Journal of Neuropathology and Experimental Neurology 65, 631-641

75 Parker, W.D., Jr. (1991) Cytochrome oxidase deficiency in Alzheimer's disease. Annals of the New York Academy of Sciences 640, 59-64

76 Terry, R.D. and Pena, C. (1965) Experimental production of neurofibrillary degeneration: electron microscopy, phosphatase histochemistry and electron probe analysis. Journal of Neuropathology and Experimental Neurology 24, 200-210

77 Crapper, D.R., Krishnan, S.S. and Dalton, A.J. (1973) Brain aluminum distribution in Alzheimer's disease and experimental neurofibrillary degeneration. Science 180, 511-513

78 Jellinger, K. et al. (1990) Brain iron and ferritin in Parkinson's and Alzheimer's diseases. Journal of Neural Transmission. Parkinson's Disease and Dementia Section 2, 327-340

79 Suh, Y.H. et al. (1996) Molecular physiology, biochemistry, and pharmacology of Alzheimer's amyloid precursor protein (APP). Annals of the New York Academy of Sciences 786, 169-183

80 Khachaturian, Z.S. (1994) Calcium hypothesis of Alzheimer's disease and brain aging. Annals of the New York Academy of Sciences 747, 1-11

81 Mori, H., Kondo, J. and Ihara, Y. (1987) Ubiquitin is a component of paired helical filaments in Alzheimer's disease. Science 235, 1641-1644

82 Lam, Y.A. et al. (2000) Inhibition of the ubiquitinproteasome system in Alzheimer's disease. Proceedings of the National Academy of Sciences of the United States of America 97, 9902-9906

83 de la Torre, J.C. and Mussivand, T. (1993) Can disturbed brain microcirculation cause 
Alzheimer's disease? Neurological Research 15, 146-153

84 Esiri, M.M. et al. (1999) Cerebrovascular disease and threshold for dementia in the early stage of Alzheimer's disease. Lancet 354, 919-920

85 Hachinski, V. and Munoz, D.G. (1997) Cerebrovascular pathology in Alzheimer's disease: cause, effect or epiphenomenon? Annals of the New York Academy of Sciences 826, 1-6

86 Snowdon, D.A. et al. (1997) Brain infarction and the clinical expression of Alzheimer's disease. The Nun Study. Journal of the American Medical Association 277, 813-817

87 De Jong, G.I. et al. (1997) Cerebrovascular hypoperfusion: a risk factor for Alzheimer's disease? Animal model and postmortem human studies. Annals of the New York Academy of Sciences 826, 56-74

88 Diaz, J.F. et al. (1991) Improved recognition of leukoaraiosis and cognitive impairment in Alzheimer's disease. Archives of Neurology 48, 1022-1025

89 Kalaria, R.N. (2000) The role of cerebral ischemia in Alzheimer's disease. Neurobiology of Aging 21, 321-330

90 Suter, O.C. et al. (2002) Cerebral hypoperfusion generates cortical watershed microinfarcts in Alzheimer disease. Stroke 33, 1986-1992

91 Miklossy, J. (2003) Cerebral hypoperfusion induces cortical watershed microinfarcts which may further aggravate cognitive decline in Alzheimer's disease. Neurological Research 25, 605-610

92 Muckle, T.J. and Roy, J.R. (1985) High-density lipoprotein cholesterol in differential diagnosis of senile dementia. Lancet 1, 1191-1193

93 Sparks, D.L. (1997) Coronary artery disease, hypertension, ApoE, and cholesterol: a link to Alzheimer's disease? Annals of the New York Academy of Sciences 826, 128-146

94 Averback, P. (1983) Two new lesions in Alzheimer's disease. Lancet 2, 1203

95 Mann, D.M., Tucker, C.M. and Yates, P.O. (1988) Alzheimer's disease: an olfactory connection? Mechanisms of Aging and Development 42, 1-15

96 Hardy, J.A. et al. (1986) An integrative hypothesis concerning the pathogenesis and progression of Alzheimer's disease. Neurobiology of Aging 7, 489-502

97 Christen-Zaech, S. et al. (2003) Early olfactory involvement in Alzheimer's disease. Canadian Journal of Neurological Sciences 30, 20-25

98 McGeer, P.L. et al. (1987) Reactive microglia in patients with senile dementia of the Alzheimer type are positive for the histocompatibility glycoprotein HLA-DR. Neuroscience Letters 79, 195-200

99 Griffin, W.S. et al. (1989) Brain interleukin 1 and S-100 immunoreactivity are elevated in Down syndrome and Alzheimer disease. Proceedings of the National Academy of Sciences of the United States of America 86, 7611-7615

100 McGeer, P.L. and Rogers, J. (1992) Antiinflammatory agents as a therapeutic approach to Alzheimer's disease. Neurology 42, 447-449

101 Schwab, C. and McGeer, P.L. (2008) Inflammatory aspects of Alzheimer disease and other neurodegenerative disorders. Journal of Alzheimer's Disease 13, 359-369

102 McGeer, P.L. and McGeer, E.G. (1995) The inflammatory response system of brain: Implications for therapy of Alzheimer and other neurodegenerative diseases. Brain Research Reviews 21, 195-218

103 McGeer, P.L. and McGeer, E.G. (2002) Local neuroinflammation and the progression of Alzheimer's disease. Journal of Neurovirology 8, 529-538

104 Webster, S. et al. (1997) Molecular and cellular characterization of the membrane attack complex, C5b-9, in Alzheimer's disease. Neurobiology of Aging 18, 415-421

105 Stewart, W.F. et al. (1997) Risk of Alzheimer's disease and duration of NSAID use. Neurology 48, 626-632

106 Zandi, P.P. et al. (2000) Reduced incidence of AD with NSAID but not $\mathrm{H} 2$ receptor antagonists: the Cache County Study. Neurology 59, 880-886

107 Veld, B.A.I. et al. (2000) Duration of non-steroidal antiinflammatory drug use and risk of Alzheimer's disease. The Rotterdam study. Neurobiology of Aging 21 (Suppl 1), S204

108 Akiyama, H. et al. (2000) Inflammation and Alzheimer's disease. Neurobiology of Aging 21, 383-421

109 Fischer, O. (1907) Miliare Nekrosen mit drusigen Wucherungen der Neurofibrillen, eine regelmässige Veränderung der Hirnrinde bei seniler Demenz. Monatsschrift für Psychiatrie und Neurologie 22, 361-372

110 Wisniewsky, H.M. (1978) Possible viral etiology of neurofibrillary changes and neuritic plaques. In Alzheimer's Disease: Senile Dementia and Related Disorders (Aging, Vol. 7) (Katzman R., Terry R.D. and Bick K.L., eds), pp. 555-557, Raven Press, New York, NA. 
111 Khachaturian, Z.S. (1985) Diagnosis of Alzheimer's disease. Archives of Neurology 42, 1097-1105

112 Hübner, A.H. (1908) Zur Histopathologie der senilen Hirnrinde. Archives of Psychiatry and Neurology 46, 598-609

113 Perusini, G. (1910) Histology and clinical findings of some psychiatric diseases of older people. In Histologie und Histopathologische Arbeiten U die Grosshirnrhinde Vol. III (Nissl, F. and Alzheimer, A., eds), pp. 297-351, Gustav Fischer, Jena (Translated by Bick, K., Amaducci, L. and Pepeu, G.).

114 Pacheco e Silva, A.C. (1926-27) Espirochetose dos centros nervos. Memorias do hospicio de Juquery, anno III-IV, 1-27

115 Pacheco e Silva, A.C. (1926) Localisation du Treponema Pallidum dans le cerveau des paralytiques généraux. Revista de Neurologia 2, 558-565

116 Schlossberger, H. and Brandis, H. (1958). Ueber Spirochaeten-befunde in Zentralnervensystem mit besonderer Berucksichtigung der syphilogenen Erkrankungen. In Handbuch der Speziellen Pathologischen Anatomie und Histologie. Dreizehnter Band, Zweiter teil, Bandteil A, Erkrankungen des Zentralen Nervensystems II (Lubarsch O., Henke F. and Roessle R., eds), pp. 1033-1172, Springer-Verlag, Berlin.

117 Rizzo, C. (1931) Ricerche sulle spirochete nel cervello dei paralitici. Riv Pathol Nerv 37, 797-814

118 Miklossy, J. (2008) Biology and neuropathology of dementia in syphilis and Lyme disease. In Dementias, Handbook of Clinical Neurology (Duyckaerts C. and Litvan I., eds), Vol. 89, pp. 825-844, Elsevier, Edinburgh, London

119 Noguchi, H. and Moore, J.W. (1913) A demonstration of Treponema pallidum in the brain of general paralysis cases. Journal of Experimental Medicine 17, 232-238

120 Merritt, H.H., Adams, R.D. and Solomon, H.C. (1946) Neurosyphilis, Oxford University Press, London

121 Bonfiglio, F. (1908) Di speciali reperti in un caso di probabile sifilide cerebrale. Deutsche Pathologische Gesellschaft 34, 196-206

122 Vinken, P.J. and Bruyn, G.W. (1978) Handbook of Neurology, Vol. 33, Chapter 17, Elsevier, Amsterdam, New York

123 Volland, W. (1938) Die Kolloide Degeneration des Gehirns bei progressiver Paralyse in ihrer Beziehung zur lokalen Amyloidose. Bulletins et mémoires de la Société médicale des hôpitaux de Paris 31, 515-520
124 Miklossy, J., Rosemberg, S. and McGeer, P.L. (2006). Beta amyloid deposition in the atrophic form of general paresis. In Alzheimer's Disease: New advances (Iqbal, K., Winblad, B. and Avila, J., eds), Medimond. International Proceedings.

Proceedings of the 10th International Congress on Alzheimer's Disease (ICAD) 2006, pp. 429-433.

125 Marshall, B.J. and Warren, J.R. (1984) Unidentified curved bacilli in the stomach of patients with gastritis and peptic ulceration. Lancet 1, 1311-1315

126 Laitinen, K. et al. (1997) Chlamydia pneumonia infection induces inflammatory changes in the aortas of rabbits. Infection and Immunity 65, 4832-4835

127 Saikku, P. (1999) Epidemiology of Chlamydia pneumoniae in atherosclerosis. American Heart Journal 138 (Suppl), 500-503

128 Mendall, M.A. et al. (1994) Relation of Helicobacter pylori infection and coronary heart disease. British Heart Journal 71, 437-439

129 Martin de Argila, C. et al. (1995) High seroprevalence of Helicobacter pylori infection in coronary heart disease. Lancet 346, 310

130 Renvert, S. et al. (2006) Bacterial profile and burden of periodontal infection in subjects with a diagnosis of acute coronary syndrome. Journal of Periodontology 77, 1110-1119

131 Zaremba, M. et al. (2007) Evaluation of the incidence of periodontitis-associated bacteria in the atherosclerotic plaque of coronary blood vessels. Journal of Periodontology 78, 322-327

132 Chiu, B. (1999) Multiple infections in carotid atherosclerotic plaques. American Heart Journal 138, S534-S536

133 Haraszthy, V.I. et al. (2000) Identification of periodontal pathogens in atheromatous plaques. Journal of Periodontology 71, 1554-1560

134 Rassu, M. et al. (2001) Demonstration of Chlamydia pneumoniae in atherosclerotic arteries from various vascular regions. Atherosclerosis 158, 73-79

135 Martin, R.J. (2006) Infections and asthma. Clinics in Chest Medicine 27, 87-98

136 MacDowell, A.L. and Bacharier, L.B. (2005) Infectious triggers of asthma. Immunology and Allergy Clinics of North America 25, 45-66

137 Micillo, E. et al. (2000) Respiratory infections and asthma. Allergy 61 (Suppl), 42-45

138 Marttila, R.J. et al. (1977) Viral antibodies in the sera from patients with Parkinson disease. European Neurology 15, 25-33

139 Rott, R. et al. (1985) Detection of serum antibodies to Borna disease virus in patients with psychiatric disorders. Science 228, 755-756 
140 Beaman, B.L. (1994). Bacteria and

neurodegeneration. In Neurodegenerative

Diseases (Caino D., ed.), pp. 319-338, W.B.

Saunders, Orlando, FL

141 Gosztonyi, G. and Ludwig, H. (1995) Borna diseaseneuropathology and pathogenesis. Current Topics in Microbiology and Immunology 190, 39-73

142 Salvatore, M. et al. (1997) Borna disease virus in brains of North American and European people with schizophrenia and bipolar disorder. Lancet 349, 1813-1814

143 Langford, D. and Masliah, E. (2003) The emerging role of infectious pathogens in neurodegenerative diseases. Experimental Neurology 184, 553-555

144 Balin, B.J. et al. (1998) Identification and localization of Chlamydia pneumoniae in the Alzheimer's brain. Medical Microbiology and Immunology 187, 23-42

145 Balin, B.J. et al. (2008) Chlamydophila pneumoniae and the etiology of late-onset Alzheimer's disease. Journal of Alzheimer's Disease 13, 371-380

146 Miklossy, J. (1993) Alzheimer's disease - a spirochetosis? Neuroreport 4, 841-848

147 Riviere, G.R., Riviere, K.H. and Smith, K.S. (2002) Molecular and immunological evidence of oral Treponema in the human brain and their association with Alzheimer's disease. Oral Microbiology and Immunology 17, 113-118

148 Miklossy, J. (2008) Chronic inflammation and amyloidogenesis in Alzheimer's disease - role of spirochetes. Journal of Alzheimer's Disease 13, 381-391

149 Miklossy, J. et al. (2004) Borrelia burgdorferi persists in the brain in chronic Lyme neuroborreliosis and may be associated with Alzheimer disease. Journal of Alzheimer's Disease 6, 1-11

150 Jamieson, G.A. et al. (1991) Latent herpes simplex virus type 1 in normal and Alzheimer's disease brains. Journal of Medical Virology 33, 224-227

151 Itzhaki, R.F. and Wozniak, M.A. (2008) Herpes simplex virus type 1 in Alzheimer's disease: the enemy within. Journal of Alzheimer's Disease 13, 393-405

152 Olichney, J.M. et al. (2000) Association between severe cerebral amyloid angiopathy and cerebrovascular lesions in Alzheimer disease is not a spurious one attributable to apolipoprotein E4. Archives of Neurology 57, 869-874

153 Luchsinger, J.A. et al. (2005) Aggregation of vascular risk factors and risk of incident Alzheimer disease. Neurology 65, 545-551

154 Voisin, T. et al. (2003) Vascular risk factors and Alzheimer's disease. La Revue de Medecine Interne 24 (Suppl), 288-291
155 Ott, A. et al. (1996) Association of diabetes mellitus and dementia: the Rotterdam Study. Diabetologia 39, 1392-1397

156 Kamer, A.R. et al. (2008) Alzheimer's disease and peripheral infections: the possible contribution from periodontal infections, model and hypothesis. Journal of Alzheimer's Disease 13, 437-449

157 Pihlstrom, B.L., Michalowicz, B.S. and Johnson, N.W. (2005) Periodontal diseases. Lancet 366, 1809-1820

158 Gibson, F.C., III et al. (2004) Innate immune recognition of invasive bacteria accelerates atherosclerosis in apolipoprotein E-deficient mice. Circulation 109, 2801-2806

159 Mattila, K.J., Pussinen, P.J. and Paju, S. (2005) Dental infections and cardiovascular diseases: a review. Journal of Periodontology 76 (Suppl), 2085-2088

160 Seppaa, B. and Ainamo, J. (1996) Dark field microscopy of the subgingival microflora in insulindependent diabetics. Journal of Clinical Periodontology 23, 63-67

161 Ling, L.J. et al. (2004) Association between human herpesviruses and the severity of periodontitis. Journal of Periodontology 75, 1479-1485

162 Heydenrijk, K. et al. (2002) Microbiota around rootform endosseous implants: a review of the literature. International Journal of Oral and Maxillofacial Implants 17, 829-838

163 O'Brien-Simpson, N.M. et al. (2004) Antigens of bacteria associated with periodontitis. Periodontology 2000 35, 101-134

164 DeGraba, T.J. (2004) Immunogenetic susceptibility of atherosclerotic stroke: implications on current and future treatment of vascular inflammation. Stroke 35 (Suppl 1), 2712-2719

$165 \mathrm{Kolb}, \mathrm{H}$. and Mandrup-Poulsen, T. (2005) An immune origin of type 2 diabetes? Diabetologia 48 , 1038-1050

166 Dewhirst, F.E. et al. (2000) The diversity of periodontal spirochetes by $16 \mathrm{~S}$ rRNA analysis. Oral Microbiology and Immunology 15, 196-202

167 Gastinel, P. (1949) Précis de bactériologie médicale. In Collections de précis médicaux. Masson and Cie, Paris

168 Trott, D.J. et al. (1997) Identification and characterization of Serpulina pilosicoli isolates recovered from the blood of critically ill patients. Journal of Clinical Microbiology 35, 482-485

169 Mikosza, A.S. et al. (2001) Comparative prevalences of Brachyspira aalborgi and Brachyspira (Serpulina) pilosicoli as etiologic agents of histologically identified intestinal spirochetosis in Australia. Journal of Clinical Microbiology 39, 347-350 
170 Burgdorfer, W. et al. (1982) Lyme disease-a tickborne spirochetosis? Science 216, 1317-1319

171 Chan, E.C. et al. (1996) Characterization of a 4.2-kb plasmid isolated from periodontopathic spirochetes. Oral Microbiology and Immunology 11, 365-368

172 Riviere, G.R. et al. (1991) Pathogen-related oral spirochetes from dental plaque are invasive. Infection and Immunity 59, 3377-3380

173 Peters, S. et al. (1999) Adherence to and penetration through cells by oral treponemes. Oral Microbiology and Immunology 14, 379-383

174 Wyss, C. et al. (2004) Treponema putidum sp. nov., a medium-sized proteolytic spirochaete isolated from lesions of human periodontitis and acute necrotizing ulcerative gingivitis. International Journal of Systematic and Evolutionary Microbiology 54, 1117-1122

175 Miklossy, J. et al. (2008) Persisting atypical and cystic forms of Borrelia burgdorferi and local inflammation in Lyme neuroborreliosis. Journal of Neuroinflammation 5, 40

176 Miklossy, J. et al. (1995) Senile plaques, neurofibrillary tangles and neuropil threads contain DNA? Journal of Spirochetal and Tickborne Diseases 2, 1-5

177 Jacquet, L. and Sézary, A. (1907) Des formes atypiques et dégénératives du tréponéme pâle. Bull mem Soc Med Hop Par 24, 114

178 MacDonald, A.B. and Miranda, J.M. (1987) Concurrent neocortical borreliosis and Alzheimer's disease. Human Pathology 18, 759-761

179 Meer-Scherrer, L. et al. (2006) Lyme disease associated with Alzheimer's disease. Current Microbiology 52, 330-332

180 Gutacker, M. et al. (1998) Arguments against the involvement of Borrelia burgdorferi sensu lato in Alzheimer's disease. Research in Microbiology 149, 31-35

181 Marques, A.R. et al. (2000) Lack of evidence of Borrelia involvement in Alzheimer's disease. Journal of Infectious Diseases 182, 1006-1007

182 Galbussera, A. et al. (2008) Lack of evidence for Borrelia burgdorferi seropositivity in Alzheimer disease. Alzheimer Disease and Associated Disorder 22, 308

183 MacDonald, A.B. (2006) Transfection "Junk" DNA - a link to the pathogenesis of Alzheimer's disease? Medical Hypotheses 66, 1140-1141

184 MacDonald, A.B. (2006) Plaques of Alzheimer's disease originate from cysts of Borrelia burgdorferi, the Lyme disease spirochete. Medical Hypotheses. 67, 592-600

185 Pappolla, M.A. et al. (1989) Concurrent neuroborreliosis and Alzheimer's disease: analysis of the evidence. Human Pathology 20, 753-757

186 Miklossy, J. (1994) The spirochetal etiology of Alzheimer's disease: A putative therapeutic approach. In Alzheimer Disease: Therapeutic Strategies. Proceedings of the Third International Springfield Alzheimer Symposium (Giacobini E. and Becker R., eds), Part I, pp. 41-48, Birkhauser, Boston

187 Miklossy, J. et al. (1994) Further morphological evidence for a spirochetal etiology of Alzheimer's Disease. NeuroReport 5, 1201-1204

188 Miklossy, J. et al. (1996) Bacterial peptidoglycan in neuritic plaques in Alzheimer's disease. Azheimer's Research 2, 95-100

189 Miklossy, J. (1998) Chronic inflammation and amyloidogenesis in Alzheimer's disease: Putative role of bacterial peptidoglycan, a potent inflammatory and amyloidogenic factor. Alzheimer's Reviews 3, 45-51

190 Hesse, L. et al. (2003) Functional and biochemical analysis of Chlamydia trachomatis MurC, an enzyme displaying UDP-N-

acetylmuramate:amino acid ligase activity. Journal of Bacteriology 185, 6507-6512

191 McCoy, A.J. et al. (2006) L,L-diaminopimelate aminotransferase, a trans-kingdom enzyme shared by Chlamydia and plants for synthesis of diaminopimelate/lysine. Proceedings of the National Academy of Sciences of the United States of America 103, 17909-17914

192 McLaughlin, R. et al. (1999) Alzheimer's disease may not be a spirochetosis. Neuroreport 10, 1489-1491

193 Mattman, L.H. (1993) Cell Wall Deficient Forms: Stealth Pathogens (2nd edn), CRC Press, Inc, Boca Raton, FL.

194 MacDonald, A.B. (1986) Borrelia in the brains of patients dying with dementia. Journal of the American Medical Association 256, 2195-2196

195 Dupuis, M.J. (1988) Multiple neurologic manifestations of Borrelia burgdorferi infection. Revista de Neurologia 144, 765-775

196 Schaeffer, S. et al. (1994) Dementia in Lyme disease. Presse Medicale 23, 861

197 Fallon, B.A. and Nields, J.A. (1994) Lyme disease: a neuropsychiatric illness. American Journal of Psychiatry 151, 1571-183 
198 Pennekamp, A. and Jaques, M. (1997) Chronic neuroborreliosis with gait ataxia and cognitive disorders. Praxis 86, 867-869

199 MacDonald, A.B. (1988) Concurrent neocortical borreliosis and Alzheimer's Disease. Annals of the New York Academy of Sciences 539, 468-470

200 Gérard, H.C. et al. (2005) The load of Chlamydia pneumoniae in the Alzheimer's brain varies with APOE genotype. Microbial Pathogenesis 39, 19-26

201 Gérard, H.C. et al. (2006) Chlamydophila (Chlamydia) pneumoniae in the Alzheimer's brain. FEMS Immunology and Medical Microbiology 48, 355-366

202 Paradowski, B. et al. (2007) Evaluation of CSFChlamydia pneumoniae, CSF-tau, and CSFAbeta42 in Alzheimer's disease and vascular dementia. Journal of Neurology 254, 154-159

203 Appelt, D.M. et al. (2008) Inhibition of apoptosis in neuronal cells infected with Chlamydophila (Chlamydia) pneumoniae. BMC Neuroscience 9, 13

204 Ring, R.H. and Lyons, J.M. (2000) Failure to detect Chlamydia pneumoniae in the late-onset Alzheimer's brain. Journal of Clinical Microbiology 38, 2591-2594

205 Kornhuber, H.H. (1996) Propionibacterium acnes in the cortex of patients with Alzheimer's disease. European Archives of Psychiatry and Clinical Neuroscience 246, 108-109

206 Kornhuber, H.H. (1996) Reply on critical comments on Propionibacterium acnes in the cortex of patients with Alzheimer's disease " by Kornhuber, H.H. (Eur Arch Psychiatry Clin Neurosci, 246:108-109) by J. Bauer; Gottfries, G.G. and Försti, H. European Archives of Psychiatry and Clinical Neuroscience 246, 226

207 Hudson, A.P. et al. (2000) Chlamydia pneumoniae, APOE genotype, and Alzheimer's disease. In Chlamydial Basis of Chronic Diseases (Dolmer L., ed.), pp. 121-36, Robert Koch Institute, Springer Verlag, New York

208 Delahaye, F. et al. (2005) Propionibacterium acnes infective endocarditis. Study of 11 cases and review of literature. Archives desMaladies Coeur et des Vaisseaux 98, 1212-1218

209 Brook, I. (2008) Microbiology and management of joint and bone infections due to anaerobic bacteria. Journal of Orthopaedic Science 13, 160-169

210 Honjo, K., van Reekum, R. and Verhoeff, N.P. (2009) Alzheimer's disease and infection: do infectious agents contribute to progression of Alzheimer's disease? Alzheimer's Dementia 5, 348-360
211 MacIntyre, A. et al. (2003) Chlamydia pneumoniae infection promotes the transmigration of monocytes through human brain endothelial cells. Journal of Neuroscience Research 71, 740-750

212 Albert, N.M. (2000) Inflammation and infection in acute coronary syndrome. Journal of

Cardiovascular Nursing 15, 13-26

213 Arking, E.J. et al. (1999) Ulrastructural analysis of Chlamydia Pneumoniae in the Alzheimer's brain. Pathogenesis 1, 201-211

214 Dreses-Werringloer, U. et al. (2006) Chlamydophila (Chlamydia) pneumoniae infection of human astrocytes and microglia in culture displays an active, rather than a persistent, phenotype.

American Journal of the Medical Sciences 332, 168-174

215 Dreses-Werringloer, U. et al. (2009) Initial characterization of Chlamydophila (Chlamydia) pneumoniae cultured from the late-onset Alzheimer brain. International Journal of Medical Microbiology 299, 187-201

216 Nochlin, D. et al. (1999) Failure to detect Chlamydia pneumoniae in brain tissues of Alzheimer's disease. Neurology 53, 1888

217 Gieffers, J. et al. (2000) Failure to detect Chlamydia pneumoniae in brain sections of Alzheimer's disease patients. Journal of Clinical Microbiology 38, 881-882

218 Preza, D. et al. (2008) Bacterial profiles of root caries in elderly patients. Journal of Clinical Microbiology 46, 2015-2021

219 Kornhuber, H.H. (1995) Chronic anaerobic cortical infection in Alzheimer's disease: Propionibacterium acnes. Neurology, Psychiatry and Brain Research 3, 177-182

220 Kornhuber, H.H. (1997) Cerebral microangiopathy, anaerobic infection and the prevention of Alzheimer's disease. Neurology, Psychiatry and Brain Research 5, 209-212

221 Howard, J. and Pilkington, G.J. (1992) Fibronectin staining detects micro-organisms in aged and Alzheimer's disease brain. Neuroreport 3, 615-618

222 Fenesy, K.E. (1998) Periodontal disease: an overview for physicians. Mount Sinai Journal of Medicine 65, 362-369

223 Kohbata, S. and Beaman, B.L. (1991) L-doparesponsive movement disorder caused by Nocardia asteroides localized in the brains of mice. Infection and Immunity 59, 181-191

224 Malaguarnera, M. et al. (2004) Helicobacter pylori and Alzheimer's disease: a possible link. European Journal of Internal Medicine 15, 381-386 
225 Kountouras, J. et al. (2006) Relationship between Helicobacter pylori infection and Alzheimer disease. Neurology 66, 938-940

226 Kountouras, J. et al. (2009) Increased cerebrospinal fluid Helicobacter pylori antibody in Alzheimer's disease. International Journal of Neuroscience 119, 765-777

227 Kountouras, J. et al. (2007) Association between Helicobacter pylori infection and mild cognitive impairment. European Journal of Neurology 14, 976-982

228 Jamieson, G.A. et al. (1992) Herpes simplex virus type 1 DNA is present in specific regions of brain from aged people with and without senile dementia of the Alzheimer type. Journal of Pathology 167, 365-368

229 Bertrand, P. et al. (1993) Distribution of herpes simplex virus type 1 DNA in selected areas of normal and Alzheimer's disease brains: a PCR study. Neurodegeneration 2, 201-208

$230 \mathrm{Xu}, \mathrm{F}$. et al. (2006) Trends in Herpes simplex virus type 1 and type 2 seroprevalence in the United States. Journal of the American Medical Association 296, 964-973

231 Sequiera, L.W. et al. (1979) Detection of herpessimplex viral genome in brain tissue. Lancet 2, 609-612

232 Middleton, P.J. et al. (1980) Herpes-simplex viral genome and senile and presenile dementias of Alzheimer and Pick. Lancet 1, 1038

233 Pogo, B.G. and Elizan, T.S. (1985) Search for viral DNA sequences in Alzheimer brain tissue. Lancet 1, 978-979

234 Pogo, B.G., Casals, J. and Elizan, T.S. (1987) A study of viral genomes and antigens in brains of patients with Alzheimer's disease. Brain 110, 907-915

235 Walker, D.G., O’Kusky, J.R. and McGeer, P.L. (1989) In situ hybridization analysis for herpes simplex virus nucleic acids in Alzheimer disease. Alzheimer Disease and Associated Disorder 3, 123-131

236 Itzhaki, R.F. et al. (1997) Herpes simplex virus type 1 in brain and risk of Alzheimer's disease. Lancet 349, 241-244

237 Itabashi, S. et al. (1997) Herpes simplex virus and risk of Alzheimer's disease. Lancet 349, 1102

238 Lin, W.R. et al. (1998) Alzheimer's disease, herpes virus in brain, apolipoprotein E4 and herpes labialis. Alzheimer's Reports 1, 173-178

239 Beffert, U. et al. (1998) HSV-1 in brain and risk of Alzheimer's disease. Lancet 351, 1330-1331

240 Beffert, U. et al. (1998) Herpes simplex virus type 1 in brain, apolipoprotein E genotype and
Alzheimer's disease. McGill Journal of Medicine 4, 4-8

241 Wozniak, M.A., Mee, A.P. and Itzhaki, R.F. (2009) Herpes simplex virus type 1 DNA is located within Alzheimer's disease amyloid plaques. Journal of Pathology 217, 131-138

242 Wozniak, M.A. et al. (2005) Productive herpes simplex virus in brain of elderly normal subjects and Alzheimer's disease patients. Journal of Medical Virology 75, 300-306

243 Renvoize, E.B., Awad, I.O. and Hambling, M.H. (1987) A sero-epidemiological study of conventional infectious agents in Alzheimer's disease. Age and Ageing 16, 311-314

244 Ounanian, A. et al. (1990) Antibodies to viral antigens, xenoantigens, and autoantigens in Alzheimer's disease. Journal of Clinical Laboratory Analysis 4, 367-375

245 Letenneur, L. et al. (2008) Seropositivity to herpes simplex virus antibodies and risk of Alzheimer's disease: a population-based cohort study. PLoSOne 3, 3637

246 Lin, W.R. et al. (2002) Herpesviruses in brain and Alzheimer's disease. Journal of Pathology 197, 395-402

247 Renvoize, E.B. et al. (1979) Possible association of Alzheimer's disease with HLA- BW15 and cytomegalovirus infection. Lancet 1, 1238

248 Aiello, A. et al. (2006) The influence of latent viral infection on rate of cognitive decline over 4 years. Journal of the American Geriatrics Society 54, 1046-1054

249 Matsuse, T. et al. (1994) Immunohistochemical and in situ hybridisation detection of adenovirus early region 1A (E1A) gene in the microglia of human brain tissue. Journal of Clinical Pathology 47, 275-277

250 Igata, T. et al. (1997) Dementia and Borna disease virus. Dementia and Geriatric Cognitive Disorders 9, 24-25

251 Yamaguchi, K. et al. (1999) Detection of borna disease virus-reactive antibodies from patients with psychiatric disorders and from horses by electrochemiluminescence immunoassay. Clinical and Diagnostic Laboratory Immunology 6, 696-700

252 Chalmers, R.M., Thomas, D.R. and Salmon, R.L. (2005) Borna disease virus and the evidence for human pathogenicity: a systematic review. QJM 98, 255-274

253 Stahl, T. et al. (2006) Viral-induced inflammation is accompanied by beta-amyloid plaque reduction in brains of amyloid precursor protein transgenic 
Tg2576 mice. European Journal of Neuroscience 24, 1923-1934

254 Rempel, H.C. and Pulliam, L. (2005) HIV-1 Tat inhibits neprilysin and elevates amyloid beta. AIDS (London, England) 19, 127-135

255 Lang, W. et al. (1989) Neuropathology of the acquired immune deficiency syndrome (AIDS): a report of 135 consecutive autopsy cases from Switzerland. Acta Neuropathologica 77, 379-390

256 Hook, E.W., III (1989) Syphilis and HIV infection. Journal of Infectious Diseases 160, 530-534

257 Comandini, U.V. et al. (1997) Chlamydia pneumoniae respiratory infections among patients infected with the human immunodeficiency virus. European Journal of Clinical Microbiology and Infectious Diseases 16, 720-726

258 Tobian, A.A. and Quinn, T.C. (2009) Herpes simplex virus type 2 and syphilis infections with HIV: an evolving synergy in transmission and prevention. Current Opinion in HIV and AIDS 4, 294-299

259 Burgos, J.S. et al. (2006) Effect of apolipoprotein E on the cerebral load of latent herpes simplex virus type 1 DNA. Journal of Virology 80, 5383-5387

260 Miller, R.M. and Federoff, H.J. (2008) Isoformspecific effects of ApoE on HSV immediate early gene expression and establishment of latency. Neurobiology of Aging 29, 71-77

261 Miklossy, J. et al. (2006) Beta-amyloid deposition and Alzheimer's type changes induced by Borrelia spirochetes. Neurobiology of Aging 27, 228-236

262 Little, C.S. et al. (2004) Chlamydia pneumoniae induces Alzheimer-like amyloid plaques in brains of BALB/c mice. Neurobiology of Aging 25, 419-429

263 Hammond, C. et al. (2006) Antibiotic alters inflammation in the mouse brain during persistent Chlamydia pnemoniae infection. In Alzheimer's Disease: New Advances (Igbal K., Winblat B. and Avila J. eds), pp. 295-299, Medimond, Bologna

264 Cribbs, D.H. et al. (2000) Fibril formation and neurotoxicity by a herpes simplex virus glycoprotein B fragment with homology to the Alzheimer's A $\beta$ peptide. Biochemistry 39, 5988-5994

265 Satpute-Krishnan, P., DeGiorgis, J.A. and Bearer, E.L. (2003) Fast anterograde transport of herpes simplex virus: role for the amyloid precursor protein of Alzheimer's disease. Aging Cell 2, 305-318

266 Wozniak, M.A. et al. (2007) Herpes simplex virus infection causes cellular beta-amyloid accumulation and secretase upregulation. Neuroscience Letters 429, 95-100
267 Zambrano, A. et al. (2008) Neuronal cytoskeletal dynamic modification and neurodegeneration induced by infection with herpes simplex virus type 1. Journal of Alzheimer's Disease 14, 259-269

268 Wozniak, M.A., Frost, A.L. and Itzhaki, R.F. (2009) Alzheimer's disease-specific tau phosphorylation is induced by herpes simplex virus type 1 . Journal of Alzheimer's Disease 16, 341-350

269 Leinonen, M. (1993) Pathogenetic mechanisms and epidemiology of Chlamydia pneumoniae. European Heart Journal 14 (Suppl), 57-61

270 Boggian, I. et al. (2000) Asymptomatic herpes simplex type 1 virus infection of the mouse brain. Journal of Neurovirology 6, 303-313

271 Valyi-Nagy, T. et al. (2000) Herpes simplex virus type 1 latency in the murine nervous system is associated with oxidative damage to neurons. Virology 278, 309-321

272 Fox, A. (1990) Role of bacterial debris in inflammatory diseases of the joint and eye. APMIS: Acta Pathologica, Microbiologica, et Immunologica Scandinavica 98, 957-968

273 Stimpson, S.A. et al. (1986) Arthropathic properties of cell wall polymers from normal flora bacteria. Infection and Immunity 51, 240-249

274 Fleming, T.J., Wallsmith, D.E. and Rosenthal, R.S. (1986) Arthropathic properties of gonococcal peptidoglycan fragments: implications for the pathogenesis of disseminated gonococcal disease. Infection and Immunity 52, 600-608

275 Palaniyar, N. et al. (2002) Pulmonary innate immune proteins and receptors that interact with gram-positive bacterial ligands. Immunobiology 205, 575-594

276 Gebbink, M.F. et al. (2005) Amyloids-a functional coat for microorganisms. Nature Reviews. Microbiology 3, 333-341

277 Hammer, N.D. et al. (2008) Amyloids: friend or foe? Journal of Alzheimer's Disease 13, 407-419

278 Gophna, U. et al. (2001) Curli fibers mediate internalization of Escherichia coli by eukaryotic cells. Infection and Immunity 69, 2659-2665

279 Ben Nasr, A. et al. (1996) Assembly of human contact phase proteins and release of bradykinin at the surface of curli-expressing Escherichia coli. Molecular Microbiology 20, 927-935

280 Olsén, A., Jonsson, A. and Normark, S. (1989) Fibronectin binding mediated by a novel class of surface organelles on Escherichia coli. Nature 338, 652-655

281 Sjöbring, U., Pohl, G. and Olsén, A. (1994) Plasminogen, absorbed by Escherichia coli 
expressing curli or by Salmonella enteritidis expressing thin aggregative fimbriae, can be activated by simultaneously captured tissue-type plasminogen activator (t-PA). Molecular Microbiology 14, 443-445

282 Hammar, M. et al. (1995) Expression of two csg operons is required for production of fibronectinand congo red-binding curli polymers in Escherichia coli K-12. Molecular Microbiology 18, 661-670

283 Umemoto, T., Li, M. and Namikawa, I. (1997) Adherence of human oral spirochetes by collagenbinding proteins. Microbiology and Immunology 41, 917-923

284 Crack, P.J. and Bray, P.J. (2007) Toll-like receptors in the brain and their potential roles in neuropathology. Immunology and Cell Biology 85, 476-480

285 Lorenz, E. et al. (2002) Relevance of mutations in the TLR4 receptor in patients with gram-negative septic shock. Archives of Internal Medicine 162, 1028-1032

286 Kiechl, S., Wiedermann, C.J. and Willeit, J. (2003) Toll-like receptor 4 and atherogenesis. Annals of Medicine 35, 164-171

287 Akira, S. and Takeda, K. (2004) Functions of toll-like receptors: lessons from $\mathrm{KO}$ mice. Comptes Rendus Biologies 327, 581-589

288 Tobias, P. and Curtiss, L.K. (2005) Thematic review series: the immune system and atherogenesis. Paying the price for pathogen protection: toll receptors in atherogenesis. Journal of Lipid Research 46, 404-411

289 Turvey, S.E. and Hawn, T.R. (2006) Towards subtlety: understanding the role of Toll-like receptor signaling in susceptibility to human infections. Clinical Immunology 120, 1-9

290 Bulut, Y. et al. (2001) Cooperation of Toll-like receptor 2 and 6 for cellular activation by soluble tuberculosis factor and Borrelia burgdorferi outer surface protein A lipoprotein: role of Tollinteracting protein and IL-1 receptor signaling molecules in Toll-like receptor 2 signaling. Journal of Immunology 167, 987-994

291 Sellati, T.J. et al. (1998) Treponema pallidum and Borrelia burgdorferi lipoproteins and synthetic lipopeptides activate monocytic cells via a CD14dependent pathway distinct from that used by lipopolysaccharide. Journal of Immunology 160, 5455-5464

292 Schroeder, N.W. et al. (2004) Lipopolysaccharide binding protein binds to triacylated and diacylated lipopeptides and mediates innate immune responses. Journal of Immunology 173, 2683-2691

293 Radolf, J.D. et al. (1995) Characterization of outer membranes isolated from Borrelia burgdorferi, the Lyme disease spirochete. Infection and Immunity 63, 2154-2163

294 Ramesh, G. et al. (2003) Pathogenesis of Lyme neuroborreliosis: Borrelia burgdorferi lipoproteins induce both proliferation and apoptosis in rhesus monkey astrocytes. European Journal of Immunology 33, 2539-2550

295 Ratner, A.J. et al. (2005) Synergistic proinflammatory responses induced by polymicrobial colonization of epithelial surfaces. Proceedings of the National Academy of Sciences of the United States of America 102, 3429-3434

296 van den Blink, B. et al. (2001) p38 mitogenactivated protein kinase inhibition increases cytokine release by macrophages in vitro and during infection in vivo. Journal of Immunology $166,582-587$

297 Van der Goot, F.G.E. (2001) Pore Forming Toxins. Springer Verlag, Berlin

298 Gekara, N.O. et al. (2007) The multiple mechanisms of $\mathrm{Ca}(2+)$ signalling by listeriolysin $\mathrm{O}$, the cholesterol-dependent cytolysin of Listeria monocytogenes. Cellular Microbiology 9, 2008-2021

299 Gonzalez, M.R. (2008) Bacterial pore-forming toxins: The $(w)$ hole story ? Cellular and Molecular Life Sciences 65, 493-507

300 Gekara, N.O. and Weiss, S. (2004) Lipid rafts clustering and signalling by listeriolysin $\mathrm{O}$. Biochemical Society Transactions 32, 712-714

301 Cossart, P. and Lecuit, M. (1998) Interactions of Listeria monocytogenes with mammalian cells during entry and actin-based movement: bacterial factors, cellular ligands and signaling. EMBO Journal 17, 3797-3806

302 Kayal, S. et al. (1999) Listeriolysin O-dependent activation of endothelial cells during infection with Listeria monocytogenes: activation of NFkappa B and upregulation of adhesion molecules and chemokines. Molecular Microbiology 31, 1709-1722

303 Hamon, M.A. et al. (2007) Histone modifications induced by a family of bacterial toxins. Proceedings of the National Academy of Sciences of the United States of America 104, 13467-13472

304 Pipkin, M.E. and Lieberman, J. (2007) Delivering the kiss of death: Progress on understanding how perforin works. Current Opinion in Immunology 19, 301-308 
305 Blanco, D.R. et al. (1999) Immunization with Treponema pallidum outer membrane vesicles induces high-titer complement-dependent treponemicidal activity and aggregation of $\mathrm{T}$. pallidum rare outer membrane proteins (TROMPs). Journal of Immunology 163, 2741-2746

306 Lawrenz, M.B. et al. (2003) Effect of complement component C3 deficiency on experimental Lyme borreliosis in mice. Infection and Immunity 71, 4432-4440

307 Kraiczy, P. et al. (2001) Mechanism of complement resistance of pathogenic Borrelia burgdorferi isolates. International Immunopharmacology 1, 393-401

308 Stanley, L.C. et al. (1994) Glial cytokines as neuropathogenic factors in HIV infection: pathogenic similarities to Alzheimer's disease. Journal of Neuropathology and Experimental Neurology 53, 231-238

309 Brabers, N.A. and Nottet, H.S. (2006) Role of the pro-inflammatory cytokines TNF-alpha and IL1 beta in HIV-associated dementia. European Journal of Clinical Investigation 36, 447-458

310 Sheng, J.G. et al. (1996) In vivo and in vitro evidence supporting a role for the inflammatory cytokine interleukin-1 as a driving force in Alzheimer pathogenesis. Neurobiology of Aging 17, 761-766

311 Goldgaber, D. et al. (1989) Interleukin 1 regulates synthesis of amyloid beta-protein precursor mRNA in human endothelial cells. Proceedings of the National Academy of Sciences of the United States of America 86, 7606-7610

312 Barger, S.W. et al. (2008) Relationships between expression of apolipoprotein $\mathrm{E}$ and beta-amyloid precursor protein are altered in proximity to Alzheimer beta-amyloid plaques: potential explanations from cell culture studies. Journal of Neuropathology and Experimental Neurology 67, 773-783

313 Li, Y. et al. (2003) Interleukin-1 mediates pathological effects of microglia on tau phosphorylation and on synaptophysin synthesis in cortical neurons through a p38-MAPK pathway. Journal of Neuroscience 23, 1605-1611

314 Sheng, J.G. et al. (2000) Interleukin-1 promotes expression and phosphorylation of neurofilament and tau proteins in vivo. Experimental Neurology 163, 388-391

315 Sheng, J.G. et al. (2001) Interleukin-1 promotion of MAPK-p38 overexpression in experimental animals and in Alzheimer's disease: potential significance for tau protein phosphorylation. Neurochemistry International 39, 341-348
316 Li, Y. et al. (2000) Neuronal-glial interactions mediated by interleukin-1 enhance neuronal acetylcholinesterase activity and mRNA expression. Journal of Neuroscience 20, 149-155

317 Zhu, S.G. et al. (1999) Increased interleukin-1beta converting enzyme expression and activity in Alzheimer disease. Journal of Neuropathology and Experimental Neurology 58, 582-587

318 Li, Y. et al. (2004) Microglial activation by uptake of fDNA via a scavenger receptor. Journal of Neuroimmunology 147, 50-55

319 Barger, S.W. and Harmon, A.D. (1997) Microglial activation by Alzheimer amyloid precursor protein and modulation by apolipoprotein E. Nature 388, 878-881

320 Tahara, K. et al. (2006) Role of toll-like receptor signalling in Abeta uptake and clearance. Brain 129, 3006-3019

321 Scholtzova, H. et al. (2009) Induction of toll-like receptor 9 signaling as a method for ameliorating Alzheimer's disease-related pathology. Journal of Neuroscience 29, 1846-1854

322 Kraiczy, P. and Würzner, R. (2006) Complement escape of human pathogenic bacteria by acquisition of complement regulators. Molecular Immunology $43,31-44$

323 Pausa, M. et al. (2003) Serum-resistant strains of Borrelia burgdorferi evade complement-mediated killing by expressing a CD59-like complement inhibitory molecule. Journal of Immunology 170, 3214-3222

324 Rasley, A., Anguita, J. and Marriott, I. (2002) Borrelia burgdorferi induces inflammatory mediator production by murine microglia. Journal of Neuroimmunology 130, 22-31

325 Hauss-Wegrzyniak, B., Vraniak, P.D. and Wenk, G.L. (2000) LPS-induced neuroinflammatory effects do not recover with time. Neuroreport 11, 1759-1763

326 Lehman, T.J. et al. (1983) Polyarthritis in rats following the systemic injection of Lactobacillus casei cell walls in aqueous suspension. Arthritis and Rheumatism 26, 1259-1265

327 Johannsen, L. (1993) Biological properties of bacterial peptidoglycan. APMIS: Acta Pathologica, Microbiologica, et Immunologica Scandinavica 101, 337-344

328 Schwab, J.H. (1993) Phlogistic properties of peptidoglycan-polysaccharide polymers from cell walls of pathogenic and normal-flora bacteria which colonize humans. Infection and Immunity $61,4535-4539$ 
329 Heiss, L.N. et al. (1994) Epithelial autotoxicity of nitric oxide: role in the respiratory cytopathology of pertussis. Proceedings of the National Academy of Sciences 91, 267-270

330 Weinberg, G. and Miklossy, J. (2008) Iron and infection. Journal of Alzheimer's Diseases 13, 451-463

331 Griffiths, E. (1991) Iron and bacterial virulence - a brief overview. Biological Methods 4, 7-13

332 Weinberg, E.D. (1992) Iron depletion: a defense against intracellular infection and neoplasia. Life Sciences 50, 1289-1297

333 Griffiths, W.J. et al. (2000) Localization of iron transport and regulatory proteins in human cells. QJM 93, 575-587

334 Goodman, L. (1953) Alzheimer's disease; a clinicopathologic analysis of twenty- three cases with a theory on pathogenesis. Journal of Nervous and Mental Disease 118, 97-130

335 Bishop, G.M. et al. (2002) Iron: a pathological mediator of Alzheimer disease? Developmental Neuroscience 24, 184-187

336 Miller, L.M.et al. (2006) Synchrotron-based infrared and $\mathrm{X}$-ray imaging shows focalized accumulation of $\mathrm{Cu}$ and $\mathrm{Zn}$ co-localized with beta-amyloid deposits in Alzheimer's disease. Journal of Structural Biology 155, 30-37

337 Lirk, P., Hoffmann, G. and Rieder, J. (2002) Inducible nitric oxide synthase - time for reappraisal. Curr Drug Targets - Inflammation and Allergy 1, 89-108

338 Chan, E.D., Chan, J. and Schluger, N.W. (2001) What is the role of nitric oxide in murine and human host defense against tuberculosis? Current knowledge. American Journal of Respiratory Cell and Molecular Biology 25, 606-612

339 Chakravortty, D. and Hensel, M. (2003) Inducible nitric oxide synthase and control of intracellular bacterial pathogens. Microbes and Infection 5, 621-627

340 Shiloh, M.U. and Nathan, C.F. (2000) Reactive nitrogen intermediates and the pathogenesis of Salmonella and mycobacteria. Current Opinion in Microbiology 3, 35-42

341 Bogdan, C. (2001) Nitric oxide and the immune response. Nature Immunology 2, 907-916

342 Ohnishi, S., Koide, A. and Koide, S. (2001) The roles of turn formation and cross- strand interactions in fibrillization of peptides derived from the OspA single-layer beta-sheet. Protein Science 10, 2083-2092

343 Otzen, D. and Nielsen, P.H. (2008) We find them here, we find them there: functional bacterial amyloid. Cellular and Molecular Life Sciences 65, 910-927

344 Chapman, M.R. et al. (2002) Role of Escherichia coli curli operons in directing amyloid fiber formation. Science 295, 851-855

345 Larsen, P. et al. (2007) Amyloid adhesins are abundant in natural biofilms. Environmental Microbiology 9, 3077-3090

346 Jordal, P.B. et al. (2009) Widespread abundance of functional bacterial amyloid in Mycolata and other Gram-positive bacteria. Applied and Environmental Microbiology 75, 4101-4110

347 Wang, X., Hammer, N.D. and Chapman, M.R. (2008) The molecular basis of functional bacterial amyloid polymerization and nucleation. Journal of Biological Chemistry 283, 21530-21539

348 Picken, M.M. (2000) The changing concepts of amyloid. Archives of Pathology and Laboratory Medicine 125, 38-43

349 Hauss-Wegrzyniak, B. and Wenk, G.L. (2002) Betaamyloid deposition in the brains of rats chronically infused with thiorphan or lipopolysaccharide: the role of ascorbic acid in the vehicle. Neuroscience Letters 322, 75-78

350 Miklossy, J. et al. (2010) Beta amyloid and hyperphosphorylated tau deposits in the pancreas in type 2 diabetes. Neurobiol Aging. 31:1503-1515

351 Kitazawa, M. et al. (2005) Lipopolysaccharideinduced inflammation exacerbates tau pathology by a cyclin-dependent kinase 5-mediated pathway in a transgenic model of Alzheimer's disease. Journal of Neuroscience 25, 8843-8853

352 Knight, J.C. and Kwiatkowski, D. (1999) Inherited variability of tumor necrosis factor production and susceptibility to infectious disease. Proceedings of the Association of American Physicians 111, 290-298

353 Shaw, M.A. et al. (2001) Association and linkage of leprosy phenotypes with HLA class II and tumour necrosis factor genes. Genes and Immunity 2, 196-204

354 Roy, S. et al. (1997) Tumor necrosis factor promoter polymorphism and susceptibility to lepromatous leprosy. Journal of Infectious Diseases 176, 530-532

355 Marangoni, A. et al. (2004) Production of tumor necrosis factor alpha by Treponema pallidum, Borrelia burgdorferi s.l., and Leptospira interrogans in isolated rat Kupffer cells. FEMS Immunology and Medical Microbiology 40, 187-191

356 Steere, A.C., Dwyer, E. and Winchester, R. (1990) Association of chronic Lyme arthritis with HLA- 
DR4 and HLA-DR2 alleles. New England Journal of Medicine 323, 21923

357 Lagrange, P.H. and Abel, L. (1996) The genetic susceptibility to leprosy in humans. Acta Leprologica 10, 11-27

358 Collins, J.S. et al. (2000) Association of a haplotype for tumor necrosis factor in siblings with lateonset Alzheimer disease: the NIMH Alzheimer Disease Genetics Initiative. American Journal of Medical Genetics 96, 823-830

359 McCusker, S.M. et al. (2001) Association between polymorphism in regulatory region of gene encoding tumour necrosis factor alpha and risk of Alzheimer's disease and vascular dementia: a casecontrol study. Lancet 357, 436-439

360 Gnjec, A. et al. (2008) Association of alleles carried at TNFA -850 and BAT1 -22 with Alzheimer's disease. Journal of Neuroinflammation 5, 36

361 Alves, C. et al. (2007) The role of the human histocompatibility antigens in the pathogenesis of neurological disorders. Revista de Neurologia 44, 298-302

362 Ballerini, C. et al. (1999) HLA A2 allele is associated with age at onset of Alzheimer's disease. Annals of Neurology 45, 397-400

363 Griffin, W.S. et al. (1995) Interleukin-1 expression in different plaque types in Alzheimer's disease: significance in plaque evolution. Journal of Neuropathology and Experimental Neurology 54, 276-281

364 Nicoll, J.A. et al. (2000) Association of interleukin-1 gene polymorphisms with Alzheimer's disease. Annals of Neurology 47, 365-368

365 Minoretti, P. et al. (2006) Effect of the functional tolllike receptor 4 Asp299Gly polymorphism on susceptibility to late-onset Alzheimer's disease. Neuroscience Letters 391, 147-149

366 Balistreri, C.R. et al. (2008) Association between the polymorphisms of TLR4 and CD14 genes and Alzheimer's disease. Current Pharmaceutical Design 14, 2672-2677

367 Urosevic, N. and Martins, R.N. (2008) Infection and Alzheimer's disease: the APOE epsilon4 connection and lipid metabolism. Journal of Alzheimer's Disease 13, 421-435

368 Licastro, F. et al. (2007) Genetic risk profiles for Alzheimer's disease: integration of APOE genotype and variants that up-regulate inflammation. Neurobiology of Aging 28, 1637-1643
369 Corder, E.H. et al. (1998) HIV-infected subjects with the E4 allele for APOE have excess dementia and peripheral neuropathy. Nature Medicine 4, 1182-1184

370 Itzhaki, R.F. et al. (2004) Infiltration of the brain by pathogens causes Alzheimer's disease. Neurobiology of Aging 25, 619-627

371 Itzhaki, R.F. and Wozniak, M.A. (2006) Herpes simplex virus type 1, apolipoprotein E, and cholesterol: a dangerous liaison in Alzheimer's disease and other disorders. Progress in Lipid Research 45, 73-90

372 Bhattacharjee, P.S. et al. (2008) Effect of human apolipoprotein E genotype on the pathogenesis of experimental ocular HSV-1. Experimental Eye Research 87, 122-130

373 Itzhaki, R.F. and Wozniak, M.A. (2010) Alzheimer's disease and infection: do infectious agents contribute to progression of Alzheimer's disease? Alzheimer's Dementia 6, 83-84

374 Perry, V.H., Cunningham, C. and Holmes, C. (2007) Systemic infections and inflammation affect chronic neurodegeneration. Nature Reviews. Immunology 7, 161-167

375 Perry, V.H., Nicoll, J.A. and Holmes, C. (2010) Microglia in neurodegenerative disease. Nature Reviews. Neurology 6, 193-201

376 Holmes, C. and Cotterell, D. (2009) Role of infection in the pathogenesis of Alzheimer's disease: implications for treatment. CNS Drugs 23, 993-1002

377 Kamer, A.R. et al. (2009) TNF-alpha and antibodies to periodontal bacteria discriminate between Alzheimer's disease patients and normal subjects. Journal of Neuroimmunology 216, 92-97

378 Blatz, R. et al. (2005) Neurosyphilis and neuroborreliosis. Retrospective evaluation of 22 cases. Der Nervenarzt 76, 724-732

379 Bolintineanu, D. et al. (2009) Antimicrobial mechanism of pore-forming protegrin peptides: 100 pores to kill E. coli. Peptides 31, 1-8

380 Kobayashi, N. et al. (2008) Binding sites on tau proteins as components for antimicrobial peptides. Biocontrol Science 13, 49-56

381 Shaftel, S.S. et al. (2007) Sustained hippocampal IL1 beta overexpression mediates chronic neuroinflammation and ameliorates Alzheimer plaque pathology. Journal of Clinical Investigation $117,1595-1604$ 
Figures

Figure 1. Distribution of spirochetes in the atrophic form of general paresis and in the frontal cortex of an Alzheimer disease (AD) patient with Lyme neuroborreliosis.

Figure 2. Spirochetes detected in the frontal cortex of neuropathologically confirmed Alzheimer disease cases. Figure 3. Sources and dissemination of pathogens associated with Alzheimer disease

Figure 4. Schematic representation of signalling pathways implicated in host-pathogen interactions in Alzheimer disease.

\section{Tables}

Table 1. Detection of spirochetes in AD.

Table 2. Detection of Chlamydophyla pneumoniae and other bacteria in AD.

Table 3. Detection of HSV-1 in AD.

\section{Citation details for this article}

Judith Miklossy (2011) Emerging roles of pathogens in Alzheimer disease. Expert Rev. Mol. Med. Vol. 13, e30, September 2011, doi:10.1017/S1462399411002006 